\title{
Ecological implications of pedogenesis and geochemistry of ultramafic soils in Kinabalu Park (Malaysia)
}

Article

Accepted Version

Creative Commons: Attribution-Noncommercial-No Derivative Works 4.0

van der Ent, A., Cardace, D., Tibbett, M. and Echevarria, G. (2018) Ecological implications of pedogenesis and geochemistry of ultramafic soils in Kinabalu Park (Malaysia). Catena, 160. pp. 154-169. ISSN 0341-8162 doi: https://doi.org/10.1016/j.catena.2017.08.015 Available at https://centaur.reading.ac.uk/73304/

It is advisable to refer to the publisher's version if you intend to cite from the work. See Guidance on citing.

To link to this article DOI: http://dx.doi.org/10.1016/j.catena.2017.08.015

Publisher: Elsevier

All outputs in CentAUR are protected by Intellectual Property Rights law, including copyright law. Copyright and IPR is retained by the creators or other copyright holders. Terms and conditions for use of this material are defined in the End User Agreement.

www.reading.ac.uk/centaur 
Central Archive at the University of Reading

Reading's research outputs online 


\title{
Ecological implications of pedogenesis and geochemistry of ultramafic soils in Kinabalu Park (Malaysia)
}

Antony van der Ent ${ }^{1,2^{*}}$, Dawn Cardace ${ }^{3}$, Mark Tibbett ${ }^{4}$, and Guillaume Echevarria ${ }^{2}$

\author{
${ }^{1}$ Centre for Mined Land Rehabilitation, Sustainable Minerals Institute, The University of \\ Queensland, Australia.
}

${ }^{2}$ Laboratoire Sols et Environnement, UMR 1120, Université de Lorraine-INRA, 54518 Vandoeuvre-lès-Nancy, France.

${ }^{3}$ Department of Geosciences, University of Rhode Island, Kingston, RI 02881, USA.

${ }^{4}$ Centre for Agri-Environmental Research \& Soil Research Centre and Soil Research Centre, School of Agriculture, Policy and Development, University of Reading, Reading, RG6 6AR, UK

*Corresponding author: a.vanderent@uq.edu.au, Centre for Mined Land Rehabilitation, The University of Queensland, St Lucia QLD 4072, Australia.

\section{ABSTRACT}

In Sabah, Malaysia, ultramafic rock outcrops are widespread (totalling $3500 \mathrm{~km}^{2}$, one of the main outcrops in the tropical zone), and predominantly of the peridotite type. However, strongly serpentinised peridotite is also locally common, particularly along fault lines in the Mt. Kinabalu area. This study aimed to determine the extent of chemical variation in ultramafic soils in relation to the degree of serpentinisation and the weathering intensity, and consequent potential ecological implications linked to resulting soil chemical fertility. It was hypothesized that young soils and derived from bedrock with a significant degree of serpentinisation strongly differ from typical geric Ferralsols and result in soil chemistries with more adverse properties to plant life (e.g. low availability of the essential nutrients $\mathrm{N}, \mathrm{P}, \mathrm{K}$ and $\mathrm{Ca}$ and high concentrations of potentially phytotoxic $\mathrm{Mg}$ and $\mathrm{Ni}$ ). Ultramafic soil diversity linked to the age of the soil or the degree of serpentinisation would thus be a main factor of plant diversity and distribution. The diverse topography of Kinabalu Park (ultramafic soils present between 400-2950 m asl) has given rise to high pedodiversity with the broad overall ultramafic soil types being: (i) deep laterite soils (Geric Ferralsols); (ii) moderately deep montane soils (Dystric Cambisols) with mor humus; (iii) shallow 
35 skeletal soils at high altitude (Eutric Cambisols Hypermagnesic); and (iv) bare serpentinite soils

36 (Hypereutric Leptosols Hypermagnesic) at low altitude (200-700 m asl). Leptosols on serpentinite

37 and Eutric Cambisols have the most extreme chemical properties in the whole Kinabalu Park area

38 both with very high $\mathrm{Mg}: \mathrm{Ca}$ molar quotients, with either high available $\mathrm{Ni}$ (Cambisols) or high $\mathrm{pH}$

39 (Leptosols). These soils host specific and adapted vegetation (high level of endemism) that tolerates

40 geochemical peculiarities, including $\mathrm{Ni}$ hyperaccumulators. Geric Ferralsol present far less

41 chemical constraints than hypermagnesian serpentine soils to the vegetation and host a tall and very

42 diverse rainforest, not so different than that on non-ultramafic soils. It therefore appears that

43 altitude, soil age and degree of bedrock serpentinisation are the main determining factors of soil

44 properties: the qualifier "ultramafic" alone is not sufficient to define soil geochemical and

45 ecological conditions in the Kinabalu Park area, probably more than in any other ultramafic region

46 in the world.

47

48 Keywords: hypermagnesian soils; laterite, $M g$ :Ca quotient, phytotoxicity, serpentinisation,

49 pedodiversity. 


\section{INTRODUCTION}

\subsection{Properties of ultramafic soils}

Ultramafic bedrock is part of the upper mantle (peridotite) obducted in continental margins (Searle and Stevens, 1984). Such outcrops are widespread but relatively rare, covering $>3 \%$ of the surface of the earth (Guillot and Hattori, 2013). The largest ultramafic regions in the world can be found in temperate (e.g. Balkans, Turkey, California) and in tropical environments (e.g. New Caledonia, Cuba, Brazil, Malaisia, Indonesia). Southeast Asia probably has the largest tropical outcrops in the world with Borneo and Sulawesi totalling over $23000 \mathrm{~km}^{2}$ (Van der Ent et al. 2013). The rock-type peridotite is made up from magnesium-iron-silicates in the minerals olivine and (ortho)pyroxene (Coleman, 1971). Low-temperature hydration and metamorphism of peridotite leads to serpentinite, usually at the sea floor along tectonic boundaries (such as near mid-ocean ridges) or during continental emplacement (Lewis et al. 2006; Guillot and Hattori, 2013). During serpentinization, the mineral assemblage is completely altered to metamorphic equivalents, and only chromite usually remains unaltered (Coleman 1971; Alexander, 2009). Serpentinite rocks contain very high $\mathrm{Mg}(18-24 \%)$ and high $\mathrm{Fe}(6-9 \%)$ but very low $\mathrm{Ca}(1-4 \%)$ and $\mathrm{Al}(1-2 \%)$ concentrations (Alexander, 2004). The total transformation of peridotite to serpentinite needs $14 \%$ water and the rock expands by $33 \%$ from dense peridotite $\left(3.2-3.3 \mathrm{~g} \mathrm{~cm}^{3}\right)$ to less dense serpentinite (2.4-2.6 $\mathrm{g} \mathrm{cm}^{3}$ ) (Alexander, 2009). This results in fracturing and shearing of the rock, and makes many serpentinite outcrops prone to landslides. As such, the weathering properties of serpentinite rocks are dramatically different from peridotite bedrock. All near-surface ultramafic rock is serpentinised to varying degrees, and serpentinite is used to describe rocks containing $>50 \%$ serpentine-group minerals (i.e. antigorite, chrysotile, lizardite) in which the original (primary, or not metamorphosed) mineralogy is obscured (following Jacobson, 1970). Ultramafic rock generally itself only contains 0.16-0.4\% nickel (Butt, 2007) however these initial concentrations increase significantly during surface weathering in humid tropical climates, resulting over the long term, in nickel laterite soils (Echevarria, 2017). Such nickel-enriched ultramafic soils are a major target for nickel and cobalt mining industries, particularly in tropical settings such as in Cuba (Roqué-Rosell et al. 2010), Brazil (Colin et al. 1991), Indonesia, the Philippines and New Caledonia (Butt, 2007; Fan \& Gerson

Properties commonly shared among ultramafic soils include high iron $(\mathrm{Fe})$ and magnesium $(\mathrm{Mg})$ concentrations and low Aluminium (Al) concentrations, relatively high concentrations of chromium complex and low concentrations of phosphorus $(\mathrm{P})$ and potassium $(\mathrm{K})$ (both total and extractable). 
In ultramafic laterites (i.e. Ferralsols), some of these features might be less strongly marked because intense weathering has erased the fingerprint of geochemical peculiarities: i.e. a higher Aluminium (Al) concentrations and a much lower magnesium-to-calcium $(\mathrm{Mg}$ :Ca) quotients than in ultramafic Cambisols or Luvisols (Echevarria, 2017).

\subsection{Geology of ultramafic outcrops in Kinabalu Park}

Ultramafic outcrops cover $3500 \mathrm{~km}^{2}$ in Sabah (Proctor et al. 1988; Repin 1998) and $151 \mathrm{~km}^{2}$ in Kinabalu Park. The ultramafic rocks are part of an ophiolite suite which derived from a collision suture between the Kalimantan micro-continent and the Sulu Arc (Imai and Ozowa, 1991) when oceanic lithosphere of the Sulu Sea was obducted (McManus and Tate, 1986). Mount Kinabalu $(4095 \mathrm{~m})$ is a granite intrusion dated 7.2 to 7.9 Ma before present (Cottam et al., 2010) and ultramafic outcrops form a 'collar-like' distribution on the mid-elevation around the Kinabalu granite core. In the northern part of Kinabalu Park lies Mount Tambuyukon (2579 m). Of the outcrops in Kinabalu Park, Mount Tambuyukon is the largest $\left(89 \mathrm{~km}^{2}\right)$, but many small outcrops $\left(<1 \mathrm{~km}^{2}\right)$ also exist. In the Kinabalu area the most common peridotite is lherzolite, and tremolitebearing peridotites whereas harzburgite and wehrlite are rare (Jacobson, 1970).

\subsection{Pedogenesis and mineralogy of ultramafic soils}

Ultramafic bedrock contains on average approximately $0.2 \% \mathrm{Ni}, 0.02 \% \mathrm{Co}, 10 \% \mathrm{Fe}$ and $0.2 \% \mathrm{Cr}$ (Butt and Cluzel, 2013). A recent article summarises the main factors involved in ultramafic pedogenesis (Echevarria, 2017). In tropical settings, weathering of ultramafic bedrock leads first to secondary phyllosilicates (Cambisols), then to amorphous and poorly-crystalline Fe-Cr-Mn oxides, and finally to crystalline Fe-oxides (Schwertmann and Latham, 1986; Becquer et al., 2006; Echevarria, 2017). On well-drained soils, peridotite minerals (olivine and pyroxenes) weather to form secondary (Fe-rich) minerals (goethite, hematite), and $\mathrm{Mg}$ and $\mathrm{Si}$ move down the soil profile and accumulate at depth (Latham, 1975b; Trescases, 1975; Proctor, 2003) whereas Fe, Cr and Al are less soluble and remain higher up in the profile. Ni is also highly leached during pedogenesis and most of it is lost in contrast to other metals, e.g. Al (Estrade et al., 2015; Echevarria, 2017). The results are deep red laterite soils consisting of a limonite (Fe-oxide) layer and a saprolite $(\mathrm{Mg}, \mathrm{Si}$ rich) layer (Gleeson et al., 2003). Total Cr concentrations are generally very high in the limonite layer. The secondary Fe and Mn oxides are known to be a major sink for Ni because of their high sorption capacity (Becquer et al. 2001), often containing 0.8-1.5 wt.\% Ni (Fan and Gerson, 2011). The Ni, Mg and Si leached into the saprolite are the main 'ore' mined in the lateritic nickel mining industry, where $\mathrm{Ni}$ is embedded in phyllosilicate minerals (Freyssinet et al., 2005) as a substitution for $\mathrm{Mg}$. This layer can contain up to $5 \mathrm{wt} . \% \mathrm{Ni}$, and in garnierite over $20 \mathrm{wt} \% \mathrm{Ni}$ (Fan and Gerson 
121 2011), but the average is $2-3$ wt.\% (Elias, 2001). The nature of secondary phyllosilicates in 122 saprolites varies according to the composition of the peridotite (total Si content) from serpentine 123 minerals to Fe-rich smectites (Raous et al., 2013). Well-drained profiles can be $20 \mathrm{~m}$ deep in the 124 Philippines (Fan and Gerson 2011) and New Caledonia (Latham 1975b; Dublet et al. 2012) or more 125 such as in Niquelândia, Brazil (Colin et al. 1990), but are usually <5 m in Sabah. These regoliths 126 are termed nickel laterites (Butt and Cluzel 2013), 'sols ferralitiques ferritiques', or Geric Ferralsols 127 (Latham 1975b; Becquer et al. 2006). Ferralsols can occur on serpentinite which produces a 128 smectite-rich saprolite material such as for pyroxenite (Echevarria, 2017). Due to the high 129 susceptibility of erosion that can affect smectite-rich saprolites, Ferralsols on serpentinite are 130 seldom observed because they are easily truncated (Echevarria 2017); such laterites, when reported, 131 are usually extremely old and occur in flat landscape positions (Youngué-Fouateu et al. 2007). 132 Ferralsols soils can also form in the montane zone on steeper slopes, but these soils are much 133 shallower and do not feature an extensive limonitic layer and often have (in the upper montane 134 zone) significant build-up of organic matter (mor-type humus). In the New Caledonian context 135 these soils are termed 'sols à accumulation humifère' (Latham 1975; 1980) or 'Inceptisols' 136 (tropepts) in the USDA classification (Burnham, 1975; Bruijnzeel et al. 1993). Between the two 137 extremes many varieties exists as a result of local erosion, colluvium and climate (Jaffré, 1992). At 138 high altitude, very shallow skeletal soils (Cambisols) form, which are a direct product of primary 139 weathering of the bedrock close to the surface. Excess Si recrystallizes to form quartz and 140 chalcedony and excess $\mathrm{Mg}$ reacts with atmospheric carbon dioxide and precipitates as magnesite 141 (Proctor 2003). These soils ('Eutric Cambisols Hypermagnesic' 'sols bruns eutrophes 142 hypermagnésiens' viz. Jaffré and Latham 1974; Latham 1975a; Jaffré 1980; or 'Hypermagnesic 143 Hypereutric Cambisols' viz. Chardot et al. 2007) have extremely high $\mathrm{Mg}: \mathrm{Ca}$ quotients as well as 144 high available $\mathrm{Ni}$ as a result of the disintegration of phyllosilicates and re-sorption onto secondary 145 Fe-oxides or high-charge clays (Bani et al. 2014; Estrade et al. 2015; Echevarria 2017).

Coleman and Jove (1992) empathised the importance of distinguishing between the weathering of peridotite, and serpentinite derived from peridotite, the first being mineralogically extremely unstable and the latter relative stable. Serpentine mineral dissolution under surface conditions is a rather low process compared to the dissolution of olivines or pyroxenes (Chardot-Jacques et al. 2013). More recently, a study showed how peridotites and serpentinites influence soil composition and metal geochemistry in a different way under temperate conditions (Kierczak et al. 2016). The mineral composition of azonal serpentinite soils (i.e. soils derived from disintegrated serpentinite colluvium, probably Cambisols) therefore contains both primary minerals (chrysotile, antigorite, lizardite) and secondary minerals (smectites, magnetite, chlorite, talc) (Chardot et al. 2007; Bani et 
al. 2014). Generally, Ferralsols and Dystric Cambisols are oligotrophic with very low base saturation and very low and low CEC respectively, whereas hypermagnesian Cambisols and serpentinitic Leptosols are eutrophic (sometimes dystrophic) with high base saturation and CEC (Echevarria, 2017). Ferralsols, as per their definition, have no weatherable minerals in the ferralic horizon. Cambisols have a $\mathrm{Bw}$ (weathering) diagnostic horizon where weatherable minerals are significant in proportion, which includes high activity clays resulting in a high CEC $\left(>24 \mathrm{cmol} \mathrm{kg}^{-}\right.$ $\left.{ }^{1}\right)$. 'Montane inceptisols' are classified as Cambisols in the WRB, but have strong connections with the specific group of Ferralsol (they have most of the ferralic properties except the depth development).

\subsection{Trace element speciation and toxicity in ultramafic soils}

Although nutrient limitations and cation imbalances have been frequently studied as a cause of the disjunct vegetation on temperate ultramafic soils (Walker et al. 1955; Proctor 1970; Nagy and Proctor 1997), relatively high total concentrations of the trace elements $\mathrm{Ni}, \mathrm{Cr}$ and $\mathrm{Co}$ in ultramafic soils have also been linked to potential phytotoxic effects (Brooks 1987; Proctor 2003). However, in humid tropical conditions, the most important factor in controlling ultramafic vegetation development seems to be soil depth (Proctor et al. 1999). The potential effects of Ni, Cr, Co and Mn toxicities on native vegetation as a whole are largely unknown, however, despite clear evidence of toxicity of these elements to plants in experimental work (Anderson et al. 1973; Taylor et al. 1991; L'Huillier et al. 1996). Nickel, in particular, has been attributed as one of the main causes for the stunting of some types of ultramafic vegetation (Brooks, 1987, Brady et al. 2005), but it is probable that other geochemical factors such as low nutrient (i.e. K and P) levels - or combinations of Ni stress and low K and P - also play a role in these phenomena (Proctor 2003). The phytotoxicity of $\mathrm{Ni}$ depends mainly on soil-specific chemistry, in particular the mineralogy of Ni-bearing phases (high-exchange clays and poorly-ordered hydrous Fe and Mn oxides contain available forms) and soil acidity ( $\mathrm{pH}$ decreases $\mathrm{Ni}$ adsorption to release phytotoxic Ni ions) (Hunter and Vergnano 1952; Crooke 1956; Halstead 1968; Echevarria 2017). In laterite soils, Ni is predominantly associated with crystallised Fe-oxides (such as goethite) and Mn-oxides (such as birnessite and lithiophorite), whereas in serpentinite soils, $\mathrm{Ni}$ is predominantly associated with phyllosilicates and smectite clay minerals when they form (Lee et al. 2003; Massoura et al. 2006; Fan and Gerson 2011; Dublet et al. 2012; Bani et al. 2014). Despite very high total concentrations, extractable/phytoavailable concentrations of chromium are generally extremely low as soil Cr-bearing minerals (such as chromite, Cr-magnetite) weather extremely slowly (Oze et al. 2004; Garnier et al. 2006). However, Cr-VI pools in such soils can reach high concentrations (approx. $0.1 \mathrm{wt} \%$ ) and they are often highly available (Garnier et al. 2009). Although Co is relatively more soluble in ultramafic soils compared 
191 to $\mathrm{Cr}$, it is present at much lower total concentrations than either that metal or $\mathrm{Ni}$, and its fate is 192 specifically associated with that of Mn. Also, very little is known about any (toxic) effects Co might 193 have on plants growing in tropical ultramafic soils.

\subsection{Ultramafic ecosystems in Kinabalu Park}

196 Kinabalu Park is renowned for its plant diversity with over 5000 recorded plant species (Beaman, 197 2005), partly the result of its variety of soils derived from a range of very contrasted bedrock types 198 ('geodiversity'). Chemical characterization of ultramafic soils is important for understanding the 199 ecology and plant/soil interactions of these ecosystems and the specific role played by intrinsic 200 ultramafic rock diversity in the overall species richness and diversity of Kinabalu Park. Although 201 the distinctiveness of ultramafic soils compared to non-ultramafic soils is often emphasized (Brooks 202 1987), it is not generally acknowledged that ultramafic soils themselves vary greatly in chemical 203 characteristics, and important differences between plant community compositions on different 204 ultramafic soils, at the same altitude, have also been observed (Borhidi 2004). Although the term 205 serpentine is frequently used to describe ultramafic geology, this is incorrect, as serpentine group 206 minerals are only a subset of those associated with ultramafic rocks (Brooks 1987; Brady et al. 207 2005). Nickel hyperaccumulator plants in Sabah were found to occur exclusively on young soils 208 that were found on strongly serpentinised bedrock (van der Ent et al. 2015; van der Ent et al. 209 2016a).

211 This study aimed to determine precisely the extent of chemical variation in ultramafic soils in 212 relation to the level of serpentinisation and weathering intensity, and consequent potential 213 ecological implications linked to soil chemical fertility. Firstly, the objective was to compare 214 ultramafic soil geochemistry to adjacent non-ultramafic soils to verify the existence of a 215 geochemical shift on this substrate. Secondly, it was hypothesized that soils young soils on 216 peridotite with low amounts of serpentine minerals and all soils derived from serpentinite (i.e. 217 containing more than 50\% serpentine minerals after Jacobson 1970) bedrocks (i.e. serpentinite vs. 218 peridotite) result in soil geochemistry with more adverse properties to plant life, which in turn 219 results in more adverse geochemical properties to plant life (e.g. low availability of essential 220 nutrients and high concentrations of potentially phytotoxic $\mathrm{Mg}, \mathrm{Cr}$ and $\mathrm{Ni}$ ). In total, 87 non221 permanent vegetation plots were established covering all major 12 'ultramafic edaphic islands' known in Kinabalu Park. In each 'island', at least four plots were laid out, with plot sizes determined by altitude. The altitude ranged from 474 to $2950 \mathrm{~m}$ above sea level (asl). 


\subsection{Site survey and sample collection}

228 Figure 1 shows the overall geology and main ultramafic outcrops in the study area. Soil profiles were observed and soil and bedrock samples were collected from 13 different ultramafic sites in Kinabalu Park, within an area of approximately $700 \mathrm{~km}^{2}$ as part of an ecological study (for details refer to Van der Ent et al. 2016b). The objective in the sampling was to account for the geological variability within ultramafic rocks (from non-serpentinised peridotite, including dunite, to serpentinite) as well as for edaphic and vegetation variability. Therefore, bedrock samples were carefully observed during the field survey to determine if they were from the serpentinite type or the non- or poorly-serpentinised peridotite type. For some of them, further X-ray diffraction mineralogy was used to confirm the observations and the local available descriptions of ultramafic rock outcrops (Jackson 1970; Imai \& Ozawa 1991; Tashakor et al. 2017). In particular, the degree of serpentinisation of peridotites is well documented in the areas of Mt. Kinabalu and Ranau (Jacobson 1970; Tashakor et al. 2017). Areas of Mt. Tambuyukon and the Serinsim lateritic plateau are much less documented (van der Ent et al. 2016a). Table 1 reports relevant site attributes (altitude, slope, bedrock type, soil type, soil depth, vegetation) and the number of samples collected from each site. At each site, at least three soil samples (1-2 kg) and one bedrock sample (2-3 kg) were collected. Each soil sample was collected in the $\mathrm{A}_{1}$ horizon, and care was taken not to include organic constituents in surface layers. The bedrock samples were collected from a soil pit at each site. The sites ranged in elevation from 474 to $2950 \mathrm{~m}$ and included a total of 95 discrete sample localities (dispersed within each ultramafic site). In addition to the shallow soil samples, five soil profiles were also excavated and samples were collected from all horizons down to the bedrock. Non-ultramafic soil and bedrock samples were collected from Kinabalu Park, near park headquarters $(1550 \mathrm{~m})$, around Layang-Layang $(2700 \mathrm{~m})$ and from nearby Mount Trus Madi (1600-2450 m) to serve as a comparison dataset to contrast the ultramafic soils and bedrock. The underlying bedrock from the non-ultramafic soils was sandstone, shale and granite. Soil profiles were described at a $36 \mathrm{~m}$ deep profile near Hampuan on strongly serpentinised peridotite (i), a $22 \mathrm{~m}$ deep profile at Sunsui with a full limonite to saprolite layering (ii), a $0.9 \mathrm{~m}$ deep profile in lateritic (Ferralsol) regolith near Serinsim (iii), and two profiles in serpentinitic Leptosols, $0.75 \mathrm{~m}$ and $0.9 \mathrm{~m}$ deep, respectively, near Wuluh River (iv and v). All soil samples were packed, brought to the local field station, air-dried at room temperature to constant weight (3-4 weeks), sieved to <2 mm, shipped to Australia, and gamma irradiated at Steritech Pty. Ltd. in Brisbane following Australian Quarantine Regulations. The rock samples were treated identically to the soils, but were dried in an 


\subsection{Laboratory analyses: soil chemistry}

262 The analysis of the soil samples took place at the laboratory of the Centre for Mined Land 263 Rehabilitation (CMLR) at The University of Queensland in Australia. The soil samples (300 mg) were digested using freshly prepared Aqua Regia $(9 \mathrm{~mL} 70 \%$ nitric acid and $3 \mathrm{~mL} 37 \%$ hydrochloric acid per sample) in a microwave for a 1.5 -hour programme and diluted to $45 \mathrm{~mL}$ with ultrapure (TDI) water before analysis. The method was based on Rayment and Higginson (1992) method 17B2. This method yields 'pseudo-total' elemental concentrations in soil matrices (viz. Rayment and Higginson, 1992). Soil pH and electrical conductivity (EC) were obtained in a 1:2.5 soil:water mixture. Plant-available phosphorus ('ML-3') was extracted with Mehlich-3 solution consisting of $\left(0.2 \mathrm{M} \mathrm{CH}_{3} \mathrm{COOH}+0.25 \mathrm{M} \mathrm{NH}_{4} \mathrm{NO}_{3}+0.015 \mathrm{M} \mathrm{NH} 4 \mathrm{~F}+0.013 \mathrm{M} \mathrm{HNO}_{3}+0.001 \mathrm{M}\right.$ EDTA at pH $2.50 \pm 0.05$ ) according to Mehlich (1984). Labile ('lab.') Ni, Co, Cr and Mn were extracted in $0.1 \mathrm{M} \mathrm{Sr}\left(\mathrm{NO}_{3}\right)_{2}$ at a soil : solution ratio of 1:4 $(10 \mathrm{~g}: 40 \mathrm{~mL})$ and 2 hours' shaking time (adapted from Kukier and Chaney, 2001). As a means of estimating potentially plant-available trace elements, DTPA-Ni, Co, Cr and Mn were extracted with Diethylene triamine pentaacetic acid (DTPA) according to Becquer et al. (1995), which was adapted from the original method by Lindsay and Norvell (1978), by the following modifications: excluding TEA, adjusted at pH 5.3, here an extraction time of 2 hours was used (instead of 1 hour) and a soil:solution ratio of 1:4 as Kukier and Chaney (2001) have demonstrated that the DTPA can be oversaturated with Ni in Nirich soils. A second method (loosely based on Feng et al. 2005) for extracting phytoavailable ('CA') $\mathrm{Ni}, \mathrm{Co}, \mathrm{Cr}$ and $\mathrm{Mn}$ was also employed, and used carboxylic acids (acetic, malic and citrate acid in molar ratio of 1:2:2 at $0.01 \mathrm{M})$ at a soil : solution ratio of $1: 4(10 \mathrm{~g}: 40 \mathrm{~mL})$ and 2 hours shaking time. Exchangeable cations ('exch.') were extracted with silver-thiourea (Dohrmann, 2006)

$\mathrm{Ni}$, Co and $\mathrm{Cr}$ partitioning was evaluated with a 5-step selective sequential extraction scheme to provide operationally defined solid-phase trace element ( $\mathrm{Ni}, \mathrm{Cr}, \mathrm{Co}, \mathrm{Mn}$ ) fractionation. This scheme is based on Quantin et al. (2002), which was in turn modified mainly from Leleyter and Probst (1999). Adaptations were made here by combining step 1 and step 2, and by using $\mathrm{HNO}_{3} / \mathrm{HF}$ highpressure microwave digests for the residual fraction (step 5) instead of an alkaline fusion as in Quantin et al. (2002). The step for the 'organic bound phase' was also omitted because the tested soils are extremely low in organic matter. As such the fractions were: water soluble and exchangeable (i), bound to Mn oxides (ii), bound to amorphous Fe oxides (iii), bound to crystalline Fe oxides (iv), and residual (v). After each extraction step, the tubes were centrifuged for 10 minutes at $4000 \mathrm{rpm}$ and the supernatants were then filtered through $0.45 \mu \mathrm{m}$ membranes. 
The residues were washed with $20 \mathrm{~mL}$ of TDI water, centrifuged again for 10 minutes at $4000 \mathrm{rpm}$, the water decanted, and the residue dried at $40^{\circ} \mathrm{C}$ prior to the next extraction step. All soil extractions were undertaken in $50 \mathrm{~mL}$ polypropylene (PP) centrifuge tubes. Soil samples were weighed using a 4-decimal balance. Samples were agitated for method-specific times using an endover-end shaker at $400 \mathrm{rpm}$, centrifuged (10 minutes at $4000 \mathrm{rpm}$ ) and the supernatant collected in $10 \mathrm{~mL}$ PP tubes. All soil samples were analysed with ICP-AES (Varian Vista Pro II) for Ni, Co, Cu, $\mathrm{Zn}, \mathrm{Mn}, \mathrm{Fe}, \mathrm{Mg}, \mathrm{Ca}, \mathrm{Na}, \mathrm{K}, \mathrm{S}$ and $\mathrm{P}$. Each method included three sample blanks, two NIST standards, two ASPAC reference soils, three random sample duplicates and three multi-element standards as part of the quality control. The ICP-AES instrument was calibrated using a 6-point multi-element standard ( $\mathrm{Ni}, \mathrm{Cu}, \mathrm{Fe}, \mathrm{Mg}, \mathrm{Ca}, \mathrm{K})$ prepared in each extraction solution.

Total elemental concentrations in rock samples $(100 \mathrm{mg})$ were obtained by digestion with a mix of $4 \mathrm{~mL} \mathrm{70 \%} \mathrm{nitric} \mathrm{acid,} 3 \mathrm{~mL} \mathrm{37 \%} \mathrm{hydrochloric} \mathrm{acid} \mathrm{and} 2 \mathrm{~mL} \mathrm{32 \%} \mathrm{hydrofluoric} \mathrm{acid} \mathrm{per} \mathrm{sample} \mathrm{in}$ a microwave for a 2-hour programme and diluted to $45 \mathrm{~mL}$ before analysis. The method was based on Rayment and Higginson (1992) method 17A2. The aliquots were also analysed with ICP-AES as 311 detailed above.

\subsection{Laboratory analyses: soil and rock mineralogy}

314 Bedrock and soil samples were analysed for mineral constituents at the University of Rhode Island, 315 Department of Geosciences (Kingston, RI). Samples were individually powdered using percussion 316 mortar and manual mortar and pestle, and passed through a 150-micron sieve. X-ray diffraction 317 (XRD) profiles were collected with an Olympus (formerly InXitu) Terra Mobile XRD System, a 318 field portable unit with extremely robust performance (Blake et al., 2012). The Terra is outfitted with a micro-focus X-ray tube (nominal operating voltage of $28 \mathrm{keV}$, filament current of $1.5 \mathrm{~A}$, cathode output of $100 \mu \mathrm{A}$ ) with a Co anode, which yields continuum and characteristic X-radiation from a $50 \mu \mathrm{m}$ diameter spot on the Co anode (Blake et al., 2012). 250 exposures generate a welldefined diffractogram for comparison with reference data files. Minerals were thus detected in the complex natural mixtures by comparing sample diffractograms with known reference diffractograms for individual minerals. Similarly, mineral phases were detected in soil samples from the profiles with a Bruker D8 Advance X-Ray diffractometer (at the University of Queensland, Australia) equipped with a copper target, diffracted-beam monochromator, and scintillation counter detector. Conditions for running the samples were: $40 \mathrm{kv}, 30 \mathrm{~mA}, 3-80^{\circ} 2 \theta$, $0.05^{\circ}$ step size or increment, with 10 seconds per step. 
330 Using the commercially available XRD peak analysis software, XPowder (available at $331 \mathrm{http} / / / \mathrm{www} . x p o w d e r . c o m /)$, relative abundances of component minerals in rocks and soils were 332 modelled as mixtures of 8 reference minerals common to ultramafic rocks using a reference 333 intensity ratio approach. The samples studied here were considered mixtures of the following 334 minerals: diopside (a pyroxene, PDF 016581), tremolite (an actinolite-type amphibole, PDF 335 011983), antigorite (a serpentine variety, PDF 018242), lizardite (a low temperature serpentine 336 variety, PDF 015238), forsterite (Mg-rich olivine, PDF 023357), spinels (representing spinel group 337 minerals including magnetite, PDF 018254), talc (PDF 019690) and montmorillonite (a smectitic 338 clay mineral, PDF 012866). Modelled proportions of these minerals should be considered estimates, 339 given for example that spinel and magnetite are binned under "spinels," multiple clay minerals 340 share the 14 to $16 \AA$ peak characteristic of smectite group clays, etc. Given that the same modelling 341 strategy was applied across all samples, relative differences in major minerals can be observed in 342 the results. Of course, modelling only provides an incomplete description of the mineralogy and 343 should be taken with much caution.

\subsection{Statistical analysis}

346 The soil and rock chemistry data was analysed using the software package STATISTICA Version 3479.0 (StatSoft), Excel for Mac version 2011 (Microsoft) and PRIMER Version 6 (PRIMER-E). The 348 XRD data was analysed with the XPowder software program (version 1.0), and with DIFFRACplus 349 Evaluation Search/Match Version 8.0 and the International Centre for Diffraction Data's PDF350 4/Minerals database. The map was prepared in ArcGIS version 10 using geological database files 351 prepared by Robert Hall (Royal Holloway University, London). Non-metric multidimensional 352 scaling (NMDS) are undoubtedly the most widely accepted and routinely used ordination technique 353 for soil and plant data. NMDS of pseudo-total soil elements (A) and exchangeable and extractable 354 elements (B) from all collection sites, contrasted with non-ultramafic comparison soils was carried 355 out. The 4 main soil types found in the areas investigated were nominally outlined in the NMDS356 plots (based on site typology, see Table 1).

\section{RESULTS}

\subsection{Bedrock elemental chemistry and mineralogy}

361 Summarized chemistry of ultramafic bedrock samples $(n=76)$ is given in Table 2. These analyses are compared with samples from non-ultramafic bedrock from Kinabalu Park and nearby Mount

363 Trus Madi ( $\mathrm{n}=13$ ). Mean concentrations of $\mathrm{Ca}, \mathrm{Co}, \mathrm{Cr}, \mathrm{Cu}, \mathrm{Fe}, \mathrm{Mg}, \mathrm{Mn}, \mathrm{Ni}$ and $\mathrm{Zn}$ are all 364 markedly higher in ultramafic rock than in non-ultramafic rock samples, whereas $\mathrm{K}, \mathrm{Na}, \mathrm{P}$ and $\mathrm{Si}$ 
are higher in non-ultramafic rock. Compared to the protolith initial concentrations, the elements $\mathrm{Al}$, $\mathrm{Ca}, \mathrm{Mg}, \mathrm{Co}, \mathrm{Ni}$ and $\mathrm{Zn}$ are significantly enriched during weathering and soil formation.

X-ray Diffraction analyses of rock samples show that minerals such as olivines (forsterite), pyroxenes (diopside, enstatite), amphibole, and spinels (chromite, magnetite) characterize the mineralogy of the peridotite bedrock (Figure 2). All ultramafic rocks present in the Kinabalu Park area are serpentinised to varying degrees, however, the more serpentinised samples also contain talc, chlorite, and magnetite as minerals in addition to serpentines, olivines and pyroxenes.

\subsection{Soil elemental chemistry}

Table 3 presents summarised bulk chemistry of ultramafic soils, contrasted with non-ultramafic soils. Mean pseudo-total concentrations of $\mathrm{Al}$ and $\mathrm{P}$ were roughly similar among soils, whereas concentrations of $\mathrm{Ca}, \mathrm{Co}, \mathrm{Cr}, \mathrm{Fe}, \mathrm{Mg}, \mathrm{Mn}$ and $\mathrm{Ni}$ were unsurprisingly much higher in ultramafic soils. On the other hand, pseudo-total concentrations of $\mathrm{K}$ were higher in non-ultramafic soils. The mean DTPA-extractable trace elements $(\mathrm{Co}, \mathrm{Cr}, \mathrm{Cu}, \mathrm{Ni}$ and $\mathrm{Zn})$ were all higher in ultramafic soils, except for Fe, which is similar. Potentially plant-available P (Mehlich-3 extract) was more than four times higher in average in non-ultramafic soils than in ultramafic soils (mean 12 vs. $2.7 \mu \mathrm{g} \mathrm{g}^{-1}$ ). The soil $\mathrm{pH}$ range was 3.5 to 9.7 for all soils. Generally, the ultramafic soils were less acidic than the non-ultramafic soils with a mean $\mathrm{pH}$ of 6.0 as opposed to the much lower value of 4.6 for nonultramafic soils. However, there was a wider range of $\mathrm{pH}$ values among ultramafic soils than among non-ultramafic soils: ultramafic laterites display acidic $\mathrm{pH}$ values as on non-ultramafic substrates whereas soils on serpentinite have unusually high $\mathrm{pH}$ values, see Table 4). Mean exchangeable $\mathrm{Ca}$, $\mathrm{Mg}$ and $\mathrm{Na}$ were much higher in ultramafic soils, and exchangeable $\mathrm{K}$ was similar between ultramafic and non-ultramafic soils (Table 3). Mean exchangeable Al was much higher in nonultramafic soils. The $\mathrm{Mg}$ :Ca in the exchangeable complex was always <1 in non-ultramafic soils (mean is 0.2) and > 1 (mean is 5.3) in ultramafic soils. Exchangeable $\mathrm{K}$ was very low and exchangeable $\mathrm{Mg}$ was relatively high, and the $\mathrm{Mg}$ :Ca molar quotient in some soils is extremely high (up to 82). Consequently, the electrical conductivity (EC) was also higher in ultramafic soils than in non-ultramafic soils. Soil pseudo-total elements of the main 'ultramafic edaphic islands' are shown in Table 4, whereas soil extractable trace elements, exchangeable macro-elements are shown

\subsection{Soil mineralogy and pedological markers in selected profiles}

Among soils, we observed several features of mineralogy and pedogenic indices of selected profiles 
serpentine-rich, with a limited smectite component, and also contained primary magnetite. In Eutric

401 Cambisols (Hypermagnesic), some of the primary minerals were still substantially present in the $\mathrm{B}_{\mathrm{W}}$ horizons. In these soils (e.g. Cambisol at Tambuyukon summit), we observed a mixture of primary silicate minerals (amphiboles, pyroxenes and talc) and secondary Fe oxihydroxides (goethite). In more developed Geric Ferralsols, no trace of primary minerals could be found except spinels (i.e. magnetite and chromite). The mineralogy of $\mathrm{B}$ lateritic horizons (i.e. ferralic horizon) was dominated by goethite (e.g. Serinsim). Pisolithes can be found at the surface of such soil profiles that usually derived from crystallisation and dehydration of oxihydroxides. General features of all soil profiles but Leptosols included relatively acidic surface horizons with a marked increase in soil $\mathrm{pH}$ and in $\mathrm{Mg}: \mathrm{Ca}$ ratios with a depth (Table 8). This rise in $\mathrm{pH}$ (and CEC) coincides with the increase in exchangeable $\mathrm{Mg}$ and $\mathrm{Ca}$ ions. Along with $\mathrm{pH}$ and $\mathrm{CEC}$ saturation increase was the increase of the $\mathrm{Mg}$ :Ca ratio with depth. Calcium was better retained by the CEC than $\mathrm{Mg}$ in $\mathrm{A}$ and

412 B horizons of Ferralsols. In the hypermagnesian Leptosols, no such differenciation was observed 413 and surface CEC was saturated by Mg.

\subsection{Metal bearing-phases and availability in soils}

416 The sequential extraction (Figure 4) showed that amorphous Fe-oxides ('AM-Fe') were important 417 phases for $\mathrm{Ni}$ and $\mathrm{Cr}$ in Eutric and Dystric Cambisols, but not in Geric Ferralsols where crystalline 418 Fe-oxides ('CR-Fe') were by far the dominating fraction of Fe-oxides. In all soils, exchangeable $\mathrm{Cr}$ 419 was extremely low (not visible on the graph), whereas exchangeable Ni in Hypereutric and Dystric 420 Cambisols was relatively high (up to several \% of total $\mathrm{Ni}$ ). In contrast, exchangeable Co was 421 extremely high in some Geric Ferralsols, but not in Hypereutric Leptosols. Residual concentrations 422 for all four elements made up $>50 \%$ of the total partitioning although many studies report incomplete dissolution of crystalline Fe-oxides with one single DCB extraction (Becquer et al.,

425 The carbolic acid extractable Co was extremely high in the Eutric Cambisols Hypermagnesic with up to $122-263 \mu \mathrm{g} \mathrm{g}^{-1}$ (on Mount Tambuyukon), whereas extremely high extractable Ni occurred in 427 both Eutric Cambisols Hypermagnesic on Mount Tambuyukon (176-404 $\mu \mathrm{g} \mathrm{g}^{-1}$ ) and in Leptosols 428 (Hypermagnesic) at Wuluh River (240-414 $\left.\mu \mathrm{g} \mathrm{g}^{-1}\right)$. Pseudo-total Mn concentrations were highest in 429 Dystric Cambisols and Cambisols (Hypermagnesic) in the high-altitude zone of Mount 430 Tambuyukon, reaching up to $33590 \mu \mathrm{g} \mathrm{g}^{-1}$, probably because of humid conditions prevailing in 431 these soils (due to the altitude). The carboxylic acid extractable Mn was also extremely high in 432 these soils (up to $3727 \mu \mathrm{g} \mathrm{g}^{-1}$ ). Likewise, pseudo-total and carboxylic acid extractable Ni were 433 similarly extremely high (up to $7000 \mu \mathrm{g} \mathrm{g}^{-1}$ and $404 \mu \mathrm{g} \mathrm{g}^{-1}$ respectively) at this location and likely to 
contribute to the toxicity of these soils. High pseudo-total $\mathrm{Cu}$ occurred on a variety of soils reaching up to $453 \mu \mathrm{g} \mathrm{g}^{-1}$, but extractable concentrations were low in all soils.

\subsection{Soil discrimination according to geochemical properties}

Figure 5 shows two NMDS-plots of pseudo-total elements (A) and exchangeable and extractable elements (B) with the 13 different sites coloured-coded (and non-ultramafic comparison soils included). In the NMDS (Figure 5), the two major sets of opposing vectors were $\mathrm{Mg}, \mathrm{Na}, \mathrm{Ca}$ and $\mathrm{Fe}, \mathrm{Cr}$, with the Hypereutric Leptosols (4) clustering along the first, and the Geric Ferralsols (1) clustering along the far end of the second. The (Hyper)Eutric Cambisols (3) spread towards the Fe, Cr vector, and the Dystric Cambisols (2) were intermediate. The non-ultramafic comparison soils clustered towards the $\mathrm{K}$ and $\mathrm{Al}$ vectors, probably because of the scarcity of these two elements in ultramafic soils. The NMDS with extractable and exchangeable elements was very different, and only the Eutric Cambisols were immediately apparent towards the exchangeable $\mathrm{Mg}$, $\mathrm{Ca}$ vector. The Eutric Cambisols clustered towards the carboxylic acid extractable Fe, Mn, Ni vector. The Dystric Cambisols were intermediate, whereas the Ferralsols clustered in the centre, which can be explained by extremely low extractable/exchangeable elements as a result of intensive leaching. The soils from Marai Parai are waterlogged and have extremely high exchangeable Al, similar to many of the sandstone-derived non-ultramafic soils. The soils from Bukit Hampuan, Bambangan and Mesilau, all localities with complex geologies that contain serpentinite bedrock, evident in bedrock analysis and in the vegetation, cluster towards the exchangeable $\mathrm{Mg}, \mathrm{Ca}$ vector.

\section{DISCUSSION}

\subsection{Characteristics and distribution of the main ultramafic soil types}

The characteristics of the (Hyper)Eutric Cambisols (Hypermagnesic) with extremely high $\mathrm{Mg}: \mathrm{Ca}$ molar quotients and very high extractable $\mathrm{Ni}$ and $\mathrm{Mn}$ concentrations results from direct and moderate weathering of the bedrock with still many primary minerals, and hence the soil chemistry is largely a reflection of that bedrock. These soils are very shallow and boulders of bedrock dominate the surface with limited signs of soil formation processes, although mineral weathering shows evident signs of the formation of a Cambic horizon with a stable complex. Also, Ni release through mineral dissolution and its uptake by neo-formed high CEC clays and poorly crystallised Fe oxides, are favourable to its high availability (Massoura et al., 2006; Chardot et al., 2007; Echevarria, 2017). In these soils, $\mathrm{Mg}$ :Ca can be as high as 70, which is strongly unbalanced to ensure ideal plant nutrition. They are mainly found at Layang-Layang (high-altitude Mount Kinabalu) and in the summit zone of Mount Tambuyukon. These shallow soils present multiple 
toxicities; extremely high phytoavailable $\mathrm{Ni}, \mathrm{Co}$ and $\mathrm{Mn}$ and extremely high exchangeable $\mathrm{Mg}$ (and high $\mathrm{Mg}: \mathrm{Ca}$ quotients) that are quite similar to those found in the ultramafic soils of the temperate and Mediterranean regions (Chardot et al., 2007; Bani et al., 2014) but also in ultramafic Eutric Cambisols from tropical regions (Borhidi 1988; Proctor 2003). In such peculiar geochemical conditions (or geochemical stress) the vegetation ranges from stunted upper montane forest (9-10 $\mathrm{m}$ ) to tufts of dwarf-scrub barely $0.3 \mathrm{~m}$ tall. Although in the cloud-zone, high wind velocity coupled with high altitude renders this a habitat with great temperature and moisture regime extremes. Similar soils occur in the summit zone of Mount Tambuyukon (2300-2570 m), and here a unique (species-rich) graminoid scrub with many endemics has developed despite the soils having such high Mg:Ca quotients and phytoavailable Ni and Mn. Therefore, altitude plays a significant role in the ultramafic stress that soils exert on the vegetation.

The most common soils in Kinabalu Park are montane Cambisols (Dystric Cambisols) that occur on moderate to steep slopes at altitudes of 900-2500 m. Particularly in the cloud forest zone, there is a thick build-up of mor humus at the surface and in some flatter and wetter areas, sphagnum peat. The typical vegetation is either open lower montane forest $(>1800 \mathrm{~m})$ or dense upper montane forest ('cloud forest') at altitudes 1800-2500 m. These soils are acidic (pH 4.5-5.8) with low CEC and intermediate $\mathrm{Mg}: \mathrm{Ca}$ quotients. These soils are very widespread in Kinabalu Park and cover most (steep slopes) of ultramafic bedrock outcrops. The formation of peat on shoulders has been attributed to the frequency of cloud-cover and hence the continuous saturation of the soil (Proctor et al., 1988). These ultramafic soils are fairly similar to the non-ultramafic soils at the same altitude and, as a consequence, few plant species are unique to the ultramafic equivalents, although stunting is more pronounced, probably due to the still unusual geochemistry: high $\mathrm{Mg}: \mathrm{Ca}$, low $\mathrm{K}$ and $\mathrm{P}$ contents, high Ni availability (Borhidi 1988; Proctor et al. 1999) because these environments are humid and the vegetation unlikely suffers from water stress. The ultramafic soils at Marai Parai (1550-1700 m) on Mount Kinabalu's west face are constantly waterlogged from water percolating from the granite summit plateau that towers above. As a result, there is peat formation and acidification of these soils and the vegetation is a graminoid scrub resembling that of the summit region of Mount Tambuyukon at much higher altitude, despite entirely different soil chemistries. They probably ressemble the "sols à accumulation humifères" described in New Caledonia above $900 \mathrm{~m}$ in many ways, including the low pH (Latham 1975a). The lack of trees might be explained by the combination of waterlogging and extremely high concentrations of exchangeable $\mathrm{Al}$ that are likely to be phytotoxic at $\mathrm{pH}$ below 5.2, although waterlogging is probably the most predominant factor. 
Finally, deep laterite soils (Geric Ferralsols) occur in low-lying areas in valleys and on plateaus where flat surfaces occur which allow for these old and intensively weathered soils to occur (Echevarria, 2017). Although not widespread in the mountainous terrain of Kinabalu Park, these types of ultramafic soils are common elsewhere in Sabah and also in many tropical settings including (Latham 1975b; Becquer et al. 2001; Proctor 2003; Garnier et al. 2009), and are particularly well developed on the Mount Tavai Plateau near Telupid. These are 'lateritic' red deep soils (up to $36 \mathrm{~m}$ has been observed at a road excavation), well-drained and frequently have marked iron concretions (ferricrete: plinthic or petroplinthic surface horizons) on the surface. Pseudo-total concentrations of $\mathrm{Fe}$ and $\mathrm{Cr}$ are extremely high, $\mathrm{CEC}$ is very low, 2:1 clay minerals are absent from 513 the soil profiles, and concentrations of extractable (i.e. plant-available) trace elements ( $\mathrm{Ni}, \mathrm{Co}, \mathrm{Cr})$ are all low. The $\mathrm{Mg}: \mathrm{Ca}$ quotient is generally low due to long and intense weathering which completely washes $\mathrm{Mg}$ out, but not $\mathrm{Ca}$. These soils are not likely to have major effects on the vegetation and do not show additional geochemical stress than in other laterites formed on nonultramafic materials. Only the presence of available Cr-VI amounts in ultramafic laterites can have some toxic effect on the biota, but it is absolutely not documented (Garnier et al., 2009). The vegetation on these soils (particularly on undulating terrain and plateaux) is very tall dipterocarpforest with a sparse understorey of tree saplings but virtually no herbs. Despite very low concentrations of (plant-available) nutrients, including $\mathrm{P}, \mathrm{Ca}$ and $\mathrm{K}$, these soils support very high biomass ecosystems. Most nutrients are contained in the living biomass, and recycling from leaf litter mass is fast (as evidenced by the distinct absence of any significant leaf litter accumulation) and efficient (as indicated by the high densities of surface roots). Geric Ferralsols are the most benign in terms of their chemical properties, notwithstanding they are (very) nutrient-poor although that in itself is not unique, as (lowland) rainforests (on non-ultramafic Ferralsols) soils are generally nutrient-poor (Whitmore 1975; Vitousek and Sanford 1986), Experimental work on these ultramafic rainforest soils has shown that nutrient-limitation rather than toxicity is likely important here (Proctor et al. 1999; Brearley, 2005).

The three major serpentinite occurrences in Kinabalu Park are located in the Wuluh Valley, the Bambangan Valley and the Panataran Valley. At these locations, rivers cut through the formations, which originally formed along major fault lines (and such topographic weaknesses are exploited by the rivers in the present day). These fault lines were fissures during emplacement through which water could circulate and interact with peridotite rock resulting in serpentinisation. Serpentinitic soils occur mainly on (extremely) steep slopes facing the respective rivers. At these localities, massive serpentinite bedrock crops out and is undercut by a river, causing cascades of landslides of fresh rock debris. The unweathered debris is rich in fine particles including mostly clay minerals (talc, smectite) but these soils have very shallow development and little weathering features, which 
539 classifies them as Hypereutric Leptosols (Hypermagnesic), the least developed ultramafic soils of 540 all. They usually develop on less than $20 \mathrm{~cm}$ and lack a $\mathrm{B}_{\mathrm{W}}$ horizon. The older soils on ridges and 541 old landslides have a thicker layer of organic matter (O-horizon) mainly made up of 'needles' of 542 Ceuthostoma sp. (Casuarinaceae) trees which decompose slowly, with a developed $\mathrm{A}_{1}$-horizon $(<20$ $543 \mathrm{~cm}$ ) and unaltered serpentinite debris underneath ( $\mathrm{C}$ horizon). The soil $\mathrm{pH}$ ranges from 6.5 in the 544 soils rich in organic matter to $\mathrm{pH} 9.8$ in the unweathered soil (C horizon and further down the 545 profile $(>50 \mathrm{~cm})$, which are extreme values for soils, comparable to those of saline soils. Some of 546 these serpentinitic Hypereutric Leptosols have extremely high carboxylic acid extractable $\mathrm{Cr}$ 547 concentrations. The high phytoavailable $\mathrm{Cr}$ concentrations in these soils is mostly due to $\mathrm{Cr}$-VI that 548 is formed during Mn oxide reduction in the clay-dominated horizons of tropical ultramafic soils 549 (Garnier et al. 2009; Raous et al. 2013). Such available Cr-VI concentrations could produce toxic 550 effects on the vegetation that could be even more adverse than available Ni pools (Reference???). 551 Some mixed soil types also exist, in particular Bambangan and Mesilau (moderately deep montane 552 soils with mor humus buildup overlying on serpentinite bedrock), and Bukit Hampuan (also 553 serpentinite bedrock, but drier eroded soils). The intermediate properties of these soils are reflected 554 in their soil chemistry (relatively high $\mathrm{pH}$, high $\mathrm{Mg}: \mathrm{Ca}$ ) as well as in the vegetation these soils 555 support (frequent occurrence of Ceuthostoma sp. - Casuarinaceae - indicative of serpentinite and 556 high $\mathrm{pH})$.

All four types are clearly distinguished by statistical analyses, which underlines their significance in terms of soil classification and later on for the interpretation of soil-vegetation relationships. In comparison with other tropical ultramafic soils from around the world (Table 9), the ultramafic soils

561 from Kinabalu Park are very diverse in their chemical properties, and some of the extractable 562 concentrations of $\mathrm{Ni}, \mathrm{Co}$ and $\mathrm{Cr}$ were recorded as exceptionally high. They usually show broader ranges of all parameters than any of the reported sites, except for total $\mathrm{Ni}$ (see data for Brazil). In particular, the existence of soils with strongly alkaline $\mathrm{pH}$ (i.e. Hypereutric Leptosols) is not reported elsewhere in tropical ultramafic regions. Although extractable $\mathrm{Cr}$ was highest in Hypereutric Leptosols, pseudo-total $\mathrm{Cr}$ was highest in Geric Ferralsols (at the Serinsim site) and comparable to the very high values found in New Caledonian or Brazilian soils.

\subsection{Effects of bedrock serpentinisation and weathering on soil types}

In the literature, soils derived from either peridotite or serpentinite bedrock are often called 'serpentine soils' and botanists and ecologists commonly do not distinguish between these two types (as emphasised by Alexander 2004; 2009). Although arguments have been made to term 
'serpentine soils' more generally 'ultramafic soils', which is geologically correct and avoids confusion with 'serpentinite', the term is cemented in the field and in literature (Brooks 1987). The differences between soils derived from 'peridotite' and 'serpentinite' are ecologically important, but they form a complex matrix of soil pedological and chemical properties that depend on weathering, altitude and topography (Jaffré 1980; Proctor et al. 1999; Kierczak et al. 2016; Echevarria 2017). It was hypothesized that soils derived from bedrock with a higher degree of serpentinisation result in soil chemistries with more adverse properties to plant life (Kierczak et al. 2016; Echevarria 2017). Two types of soils turned out to have extreme chemical properties however: (i) soils derived from peridotite at high altitude - (Hyper)Eutric Cambisols (Hypermagnesic) - where rejuvenation through erosion maintains soils at an early weathering stage (Echevarria, 2017), and (ii) soils derived from strongly serpentinised bedrock - serpentinitic Hypereutric Leptosols (Hypermagnesic) - whose evolution is slow because of their unusual mineralogical composition (i.e. dominated by slowly-weathered serpentine and talc minerals).

Fully developed laterites (Geric Ferralsols) show much lesser influence of the original ultramafic material. For instance, $\mathrm{pH}$ values, exchangeable $\mathrm{Ca}$ over exchangeable $\mathrm{Mg}$, exchangeable $\mathrm{Ni}$ are more similar to other Ferralsols developed on non-ultramafic materials. In Ferralsols, Ni is borne mainly by crystallised Fe-oxides and the resulting availability is extremely low (Becquer et al. 2006; Massoura et al. 2006; Raous et al. 2013). In contrast, Cr-VI available pool can be significantly elevated (>1000 $\mu_{\mathrm{g} \mathrm{g}^{-1}}$ ) also in these soils (Garnier et al. 2009; Raous et al. 2013) and thus represent a significant constraint for the vegetation, especially with the lack of phosphorus due to ultramafic conditions. The chromate ions in excess interfere with the uptake of phosphate ions by plants. This geochemical stress for plants that is only found in ultramafic laterites has not been investigated thoroughly, although could be a major pressure for plant adaptation.

\subsection{How ultramafic soil diversity does influence floristic patterns?}

Deep laterite soils (Geric Ferralsols) developed on undulating terrain, either over peridotite or strongly serpentinised peridotite, were characterised by extremely high pseudo-total $\mathrm{Fe}$ and $\mathrm{Cr}$, low CEC (0.1-2 cmol/kg), acidic ( $\mathrm{pH} 4.5-5.5)$ and low exchangeable Mg (but also low exchangeable $\mathrm{Ca}$ and K). Distribution: Serinsim, Nalumad. These deep ultramafic Geric Ferralsols support tall species-rich rainforest, not dissimilar to podzolised sandstone nutrient-poor forests elsewhere in Sabah, with the dipterocarps Shorea laxa and Shorea venulosa and the gymnosperm Agathis borneensis (Araucariaceae) dominating. Other characteristic dipterocarps include Dipterocarpus lowii, D. ochraceus, Shorea kunstleri, S. laxa, S. lowii, S. tenuiramulosa, S. venulosa and Dryobalanops beccarii (Acres et al. 1975; Ashton 1982). Comparable rainforests growing on Geric 
609 Ferralsols at low altitude (because of the lack of water limitation) are found in the area of Moa in 610 Cuba (Borhidi 1988), in alluvial soils of Rivière Bleue in New Caledonia (Jaffré 1980, 1992; Isnard 611 et al. 2016) and in the Philippines, despite a high rainfall, there is no such forest development as in 612 this region of Sabah. Some authors suspect that fire is involved in the lack of forest development on 613 Ferralsols that can be observed in many places with no apparent effect of edaphic conditions 614 (Proctor 2003). It is clearly the fact in New Caledonia, where the rainforest is now limited to 615 alluvial plains in low altitudes (Isnard et al. 2016).

Moderately deep montane soils (Dystric Cambisols) frequently with high build-up of organic matter (mor humus) are acidic ( $\mathrm{pH} 5-6)$, have with high exchangeable $\mathrm{Al}$, but low CEC (1-3 $\mathrm{cmol} \mathrm{kg}^{-1}$ ) and high pseudo-total Fe, Cr and Ni. Distribution: Mesilau, Bukit Babi, Bambangan, Marai Parai, Bukit Hampuan, Mount Tambuyukon (slopes), Mount Nambuyukon. The Dystric Cambisols are the most widespread soils in the 'cloud-forest' zone of Kinabalu Park. The tree density is generally high and these ecosystems have high species diversity, particularly in epiphytes such as orchids. The vegetation is typical for this altitudinal zone, and dominated by trees in the families Myrtaceae, Fagaceae, Podocarpaceae and Rubiaceae. The vegetation, however, differs little from soils derived from non-ultramafic bedrock in the same area, although physiognomy is often more stunted on the ultramafic soils for reasons not fully understood. Strongly serpentinized soils on high altitude (Bukit Hampuan, Bambangan, Mesilau) have Dystric Cambisols, but these are much more base-rich (CEC, $\mathrm{pH}$ ) and have higher $\mathrm{Mg}: \mathrm{Ca}$ quotients compared to peridotite-derived ultramafic soils or non-ultramafic soils, which is reflected in extremely species-rich vegetation.

Very shallow skeletal soils on high-altitude $(2400-2950 \mathrm{~m})$ weathered peridotite with very little organic matter (Eutric/Hypereutric Cambisols Hypermagnesic). These soils are very young and rejuvenated by erosion and are characterised by extremely high pseudo-total and exchangeable $\mathrm{Mg}$, low CEC (3-5 cmol kg-1), very high extractable Ni (50-180 $\mu \mathrm{g} \mathrm{g}^{-1}$ DTPA-Ni) and Mn (250-500 $\mu \mathrm{g} \mathrm{g}^{-1}$ DTPA-Mn), and are moderately acidic ( $\mathrm{pH}$ 5-5.8). Distribution: Mount Tambuyukon 636 (summit), Layang-Layang. The skeletal Eutric Cambisols are extreme in their chemical properties (high Mg:Ca, high extractable $\mathrm{Ni}$ and $\mathrm{Mn}$ ), and coupled with high altitude (2400-2950 m) have given rise to very stunted vegetation dominated by species in the Myrtaceae and Podocarpaceae at Layang-Layang on Mount Kinabalu's south slope. On the more exposed slopes, the vegetation is co-dominated by just two plant species, Leptospermum recurvum (Myrtaceae) and Dacrydium 641 gibbsiae (Podocarpaceae), both endemic. Locally, the carnivorous pitcher plant Nepenthes villosa 642 (Nepenthaceae), also endemic, is common. The ultramafic graminoid vegetation ( $<1 \mathrm{~m} \mathrm{high}$ ) on the exposed summit ridges of Mount Tambuyukon is unique and not found anywhere else in Sabah or 
644 Borneo. This vegetation type is characterized by a range of shrubs such as Tristaniopsis elliptica 645 (Myrtaceae), Lithocarpus rigidus (Fagaceae), Ternstroemia lowii (Pentaphylacaceae), Scaveola 646 verticillata (Goodeniaceae), Wikstroemia indica (Thymelaeaceae), Leptospermum recurvum 647 (Myrtaceae), Podocarpus brevifolius and Dacrydium gibbsiae (Podocarpaceae), the sedges, Gahnia javanica and Schoenus melanostachys.

Soils developed on bare serpentinite (serpentinitic hypermagnesic Leptosols) at low altitude (400$700 \mathrm{~m}$ ) have high total and exchangeable $\mathrm{Mg}(\mathrm{Mg}: \mathrm{Ca} 5-25)$, very high CEC (15-25 $\left.\mathrm{cmol} \mathrm{kg}^{-1}\right)$, 652 high extractable $\mathrm{Ni}\left(20-50 \mu \mathrm{g} \mathrm{g}^{-1} \mathrm{DTPA} \mathrm{Ni}\right)$ and circum-neutral $\mathrm{pH}(6.5-7.5)$ near the surface and 653 highly alkaline at depth ( $\mathrm{pH} 8-9.5)$. Distribution: Panataran Valley, Wuluh River. The serpentinitic 654 Leptosols give rise to a mosaic of landslides, with the older landslides and the ridges having open medium-tall forest dominated by Casuarinaceae (Gymnostoma sumatranum, G. nobile and 656 Ceuthostoma terminale) whereas the younger landslides have pioneer communities often with 657 shrubs of Scaevola micrantha (Goodeniaceae), Decaspermum vitis-idaea (Myrtaceae) and 658 Macaranga kinabaluensis (Euphorbiaceae). Two terrestrial hyper-endemic orchids, Paphiopedilum 659 rothschildianum and $P$. dayanum, are restricted to this pioneer vegetation. Another hyper-endemic, 660 the tree Borneodendron aenigmaticum (Euphorbiaceae), co-occurs with Casurinaceae in more 661 developed forest. It is difficult to compare these soils with other regions in the world. In the region of Moa of Cuba, these soil types (Cambic Leptosols or Hypereutric Leptic Cambisols) are those which display the highest rate of endemism (Borhidi 1988).

Numerous experimental studies have demonstrated Ni-toxicity in plants in ultramafic soils (for example L'Huillier et Edighoffer. 1996; Kukier and Chaney 2001), but some rare plant species actually thrive in Ni-rich soils. These plants, nickel hyperaccumulator species, plants that sequester in excess of $1000 \mu \mathrm{g} \mathrm{g}^{-1} \mathrm{Ni}$ in their shoots (Van der Ent et al. 2013) are also known from Sabah (Proctor et al., 1988; Van der Ent et al., 2016b). Their occurrence in Sabah (van der Ent et al., 2016a) is restricted to soils with exceptionally high available $\mathrm{Ni}$, mainly strongly serpentinised soils in the lowlands $(<1200 \mathrm{~m}$ asl). These occurrences are localized on very shallow soils with active mineral weathering. In such soils, the dissolution of primary minerals releases $\mathrm{Ni}$, which is then made available by adsorption onto high CEC clays and non-crystallised Fe-oxides. This allow Ni exchangeable pools to be high enough to favour Ni hyperaccumulation by specialised species, for example in Nalumad where the strongly serpentinised soils also have very high pseudo-total Mn (8698-16 $120 \mu \mathrm{g} \mathrm{g}^{-1}$ ) and up to $300 \mu \mathrm{g} \mathrm{g}^{-1}$ DTPA-Mn and 276-654 $\mu \mathrm{g} \mathrm{g}^{-1}$ DTPA-Cr. The occurrence of Ni-hyperaccumulators in ultramafic areas of Sabah has been shown to be strictly correlated with high-Mg soils and it was never reported on laterites (van der Ent et al., 2016a). 
680 Finally, as reported in other studies from other tropical ultramafic regions of the world, the floristic 681 zonation with altitude is more pronounced on ultramafic substrates than on non-ultramafic 682 substrates. It is the case for example in the region of Moa (Borhidi 1988) and also in Mount Silam 683 in Sabah (Proctor 2003). The reasons why it is the case are probably due to the geochemistry of the 684 soils (altitude soils are mostly Dystric or Hypereutric Cambisols because of the slope that 685 rejubvenates the profiles).

\section{CONCLUSIONS}

688 The occurrence and chemical characteristics of these soils are a function of bedrock mineralogy 689 (serpentinisation), weathering and landscapes attributes (altitude, slope). Overall, ultramafic soils 690 are less acidic, have higher EC, higher pseudo-total $\mathrm{Ca}, \mathrm{Co}, \mathrm{Cr}, \mathrm{Fe}, \mathrm{Mg}, \mathrm{Mn}$ and $\mathrm{Ni}$, higher 691 exchangeable $\mathrm{Ca}$ and $\mathrm{Mg}$, higher $\mathrm{Mg}: \mathrm{Ca}$ quotients, similar exchangeable $\mathrm{K}$, higher DTPA692 extractable $\mathrm{Co}, \mathrm{Cr}, \mathrm{Cu}$ and $\mathrm{Ni}$, and lower chemically-extractable $\mathrm{P}$ than adjacent non-ultramafic 693 soils. Well-developed Geric Ferralsols probably show less differences from non-ultramafic soils 694 under similar conditions than high altitude soils or shallow erosion-rejuvenated Cambisols. 695 Therefore they host ecosystems that show little difference with those present in soils developed on 696 other types of bedrocks. On the contrary, ultramafic Leptosols or shallow hypermagnesic Cambisols 697 that form on serpentinite substrates host specific and adapted vegetation (high level of endemism) 698 that tolerates geochemical peculiarities, including $\mathrm{Ni}$ hyperaccumulators. Whether soils are 699 moderately or weakly weathered due to the original mineralogy (i.e. strongly serpentinised bedrock) 700 or due to lack of evolution (high-slope erosion/rejuvenation), the so-called 'serpentine syndrome' 701 only seems to restricted to these two types of soils. However, the geochemical Cr anomaly (i.e. high 702 levels of exchangeable Cr-VI) of ultramafic laterites probably exerts strong effects on the 703 vegetation but this has never been studied. The lack of strong differences with lowland forests on 704 other geological substrates tends to hide this phenomenon.

The highest level of edaphic stress is therefore concentrated on fully serpentinised ultramafic outcrops, which should be prioritised areas for the search for endemic plants on ultramafic

\section{ACKNOWLEDGMENTS}

711 We wish to thank Sabah Parks for their support and the SaBC for granting permission for 712 conducting research in Sabah, and to extend our gratitude to Kalipin Al-Hafsan Bin Sampin and 713 Hali bin Nassim in the field, and Vanessa Ullmann in the laboratory. We thank Robert Hall (Royal 
Holloway University of London, SE Asia Research Group. Department of Earth Sciences, UK) for

715 the geology geospatial data and helpful advice. We thank Peter Erskine (University of Queensland)

716 for preparation of Figure 1. The University of Queensland is gratefully acknowledged for financial 717 support that made this project possible. The French National Research Agency through the national 718 "Investissements d'avenir" program (ANR-10-LABX-21, LABEX RESSOURCES21) is 719 acknowledged for funding A. van der Ent's post-doctoral position in 2014-2015. A. van der Ent is 720 the recipient of a Discovery Early Career Researcher Award (DE160100429) from the Australian 721 Research Council.

\section{REFERENCES}

724 Alexander, E.B. (2004) Serpentine soil redness, differences among peridotite and serpentinite materials, Klamath Mountains, California. International Geology Review: 46(8), 754-764 pp.

Alexander, E.B. (2009) Soil and Vegetation Differences from Peridotite to Serpentinite. Northeastern Naturalist: 16(5), 178-192 pp.

Alexander, E.B. and Coleman, R. (2004)

Anderson, A.J., Meyer, D.R. and Mayer, F.K. (1973) Heavy metal toxicities: levels of nickel, cobalt, and chromium in the soil and plants associated with visual symptoms and variation in growth of an oat crop. Australian Journal of Agricultural Research: 24, 557-571 pp.

Bani, A., Echevarria, G., Montargès-Pelletier, E., Gjoka, F., Sulçe, S., Morel, J.L. (2014). Pedogenesis and nickel biogeochemistry in a typical Albanian ultramafic toposequence. Environmental Monitoring and Assessment: 186: 4431-4442.

Becquer, T., Bourdon, E., and Pétard, J. (1995) Disponibilité du nickel le long d'une toposéquence de sols développés sur roches ultramafiques de Nouvelle-Calédonie. Comptes rendus de l'Académie des sciences: Série 2. Sciences de la terre et des planètes, 321(7), 585-592 pp.

744 Becquer, T., Pétard, J., Duwig, C., Bourdon, E., Moreau, R. and Herbillon, A.J. (2001) 745 Mineralogical, chemical and charge properties of Geric Ferralsols from New Caledonia. Geoderma: 746 103(3), 291-306 pp. 
Becquer T, Quantin C, Rotté-Capet S, Ghanbaja J, Mustin C, Herbillon AJ (2006) Sources of trace metals in Ferralsols in New Caledonia. European Journal of Soil Science 57, 200-213.

Beaman, J. H. (2005). Mount Kinabalu: hotspot of plant diversity in Borneo. Biologiske Skrifter, $55,103-127$.

Blake, D., Vaniman, D., Achilles, C., Anderson, R., Bish, D., Bristow, T. Chen, C., Chipera, S., Crisp, J., Des Marais, D., Downs, R.T., Farmer, J., Feldman, S., Fonda, M., Gailhanou, M., Ma, H., Ming, D.W.,Morris, R.V., Sarrazin, P., Stolper, E., Treiman, A. and Yen, A. (2012) Characterization and Calibration of the CheMin Mineralogical Instrument on Mars Science Laboratory. Space Science Reviews: 170, (1-4).

Borhidi, A.L. (1988) The ecological effect of serpentine rock to the flora and vegetation of Cuba. Acta Botanica Hungarica 34(1-2) 123-174 pp.

Brady, K.U., Kruckeberg, A.R. and Bradshaw, H.D. Jr. (2005) Evolutionary ecology of plant adaptation to serpentine soils. Annual Review of Ecology, Evolution, and Systematics: 243-266 pp. Brooks, R.R. (1987) Serpentine and its vegetation: a multidisciplinary approach, Dioscorides Press, $462 \mathrm{pp}$.

Burnham, C.P. (1975) The Forest environment: soil. In: Tropical rain forests of the Far East. Whitmore, T.C. Clarendon Press, Oxford.

Bruijnzeel, L., Waterloo, M., Proctor, J., Kuiters, A., \& Kotterink, B. (1993). Hydrological observations in montane rain forests on Gunung Silam, Sabah, Malaysia with special reference to the "Massenerhebung” effect. Journal of Ecology, 81(1), 145-167.

Butt, CRM (2007) Nickel Laterites, CRC LEME, CSIRO Exploration and Mining.

Butt, C.R.M. and Cluzel, D. (2013) Nickel Laterite Ore Deposits: Weathered Serpentinites. Elements: 9(2), 123-128 pp.

Chardot, V., Echevarria, G., Gury, M., Massoura, S. and Morel, J. L. (2007) Nickel bioavailability in an ultramafic toposequence in the Vosges Mountains (France). Plant and Soil: 293(1-2), 7-21 pp. 
782 Chardot-Jacques, V., Calvaruso, C., Simon, B., Turpault, M.-P., Echevarria, G., Morel, J.L. (2013)

783 Chrysotile dissolution in the rhizosphere of the nickel hyperaccumulator Leptoplax emarginata.

784 Environmental Science \& Technology 47(6), 2612-2620 pp.

786 Coleman, R.G. (1971) Petrologic and geophysical nature of serpentinites. Geological Society of 787 America Bulletin: 82, 897-918 pp.

Coleman, R.G. and Jove, C. (1992) Geological origin of serpentinites. In: The vegetation of ultramafic (serpentine soils). Baker, A.J.M., Proctor, J. and Reeves, R.D. (editors), Intercept, UK. $791 \quad 1-18 \mathrm{pp}$.

Colin, F., Nahon, D., Trescases, J.J., Melfi, A.J. (1990) Lateritic weathering of pyroxenites at Niquelândia, Goiás, Brazil: The supergene behavior of nickel. Economic Geology: 85, 1010-1023 pp.

Cottam, M., Hall, R., Sperber, C. and Armstrong, R. (2010) Pulsed emplacement of the Mount Kinabalu granite, northern Borneo. Journal of the Geological Society: 167(1), 49-60 pp.

Crooke, W.M. (1956) Effect of soil reaction on uptake of nickel from a serpentine soil. Soil

Dohrmann, R. (2006). Cation exchange capacity methodology II: A modified silver-thiourea 805 method. Applied Clay Science: 34(1-4), 38-46 pp.

Dublet, G., Juillot, F., Morin, G., Fritsch, E., Fandeur, D., Ona-Nguema, G., \& Brown, G. E., Jr. (2012). Ni speciation in a New Caledonian lateritic regolith: A quantitative X-ray absorption 809

810 Echevarria G. 2017. Genesis and behaviour of ultramafic soils and consequences for nickel 811 biogeochemistry. In Baker A.J.M., Echevarria G., Morel J.L. and van der Ent A. (Eds): 812 Agromining: extracting unconventional resources from plants, Mineral Resource Reviews series, 813 SpringerNature [In Press]

815 Elias M. (2001) Nickel laterite deposits - geological overview, resources and exploitation. In: 816 Giant Ore Deposits: Characteristics, genesis and exploration. Cooke, D.R. and Pongratz, J. 
(editors), CODES Special Publication 4, Centre for Ore Deposit Research, University of Tasmania, 205-220 pp.

van der Ent, A., Baker, A. J. M., van Balgooy, M. M. J., \& Tjoa, A. (2013). Ultramafic nickel laterites in Indonesia (Sulawesi, Halmahera): Mining, nickel hyperaccumulators and opportunities for phytomining. Journal of Geochemical Exploration, 128, 72-79.

van der Ent A, Erskine PD, Sumail S (2015) Ecology of nickel hyperaccumulator plants from ultramafic soils in Sabah (Malaysia). Chemoecology 25(5): 243-259.

van der Ent A, Echevarria G, Tibbett M (2016a) Delimiting soil chemistry thresholds for nickel hyperaccumulator plants in Sabah (Malaysia). Chemoecology 26: 67-82.

van der Ent A, Erskine PD, Mulligan DR, Repin R, Karim R (2016b) Vegetation on ultramafic edaphic islands in Kinabalu Park (Sabah, Malaysia) in relation to soil chemistry and altitude. Plant and Soil, 403: 77-101.

Estrade, N., Cloquet, C., Echevarria, G., Sterckeman, T., Deng, T-H-B., Tang, Y-T., Morel, J.L. (2015). Weathering and vegetation controls on nickel isotope fractionation in surface ultramafic environments (Albania). Earth and Planetary Science Letters: 423, 24-35 pp.

Fan, R. and Gerson, A.R. (2011) Nickel geochemistry of a Philippine laterite examined by bulk and microprobe synchrotron analyses. Geochimica et Cosmochimica Acta: 75(21), 6400-6415 pp.

Feng, M., Shan, X., Zhang, S. and Wen, B. (2005) A comparison of the rhizosphere-based method with DTPA, EDTA, $\mathrm{CaCl}_{2}$, and $\mathrm{NaNO}_{3}$ extraction methods for prediction of bioavailability of metals in soil to barley. Environmental Pollution: 137(2), 231-240 pp.

Freyssinet, P., Butt, C.R.M. and Morris, R.C. (2005) Ore-forming processes related to lateritic weathering. Economic Geology: 100, 681-722 pp.

Garnier, J., Quantin, C., Echevarria, G. and Becquer, T. (2009). Assessing chromate availability in tropical ultramafic soils using isotopic exchange kinetics. Journal of Soils and Sediments 9: 468475. 
852 Garnier, J., Quantin, C., Martins, E. S. and Becquer, T. (2006) Solid speciation and availability of 853 chromium in ultramafic soils from Niquelāndia, Brazil. Journal Of Geochemical Exploration: 88(1854 3), 206-209 pp.

855

856 Gleeson, S.A., Butt, C.R.M. and Elias, M. (2003) Nickel laterites: a review. Society of Economic 857 Geology Newsletter 54, 1-18.

859 Guillot, S. and Hattori, K. (2013) Serpentinites: Essential Roles in Geodynamics, Arc Volcanism, 860 Sustainable Development, and the Origin of Life. Elements: 9(2), 95-98 pp.

862 Halstead, R.L. (1968) Effect of different amendments on yield and composition of oats grown on a 863 soil derived from serpentine material. Canadian Journal of Soil Science: 48, 301-305 pp.

Hunter, J.G. and Vergnano, O. (1952) Nickel toxicity in plants. Annals of Applied Biology: 39, 866 279-284 pp.

Imai, A. and Ozawa, K. (1991) Tectonic implications of the hydrated garnet peridotites near Mt

Jacobson, G. (1970) Gunung Kinabalu area, Sabah, Malaysia. Explanation of part of sheers 5-116-3

Jaffré, T. (1980) Etude écologique du peuplement végétal des sols dérivés de roches ultrabasiques en Nouvelle- Calédonie. Paris: ORSTOM

Jaffré, T. (1992) Floristic and ecological diversity of the vegetation on ultramafic rocks in New

Jaffré, T., Latham, M. (1974) Contribution à l'étude des relations sol-végétation sur un massif de roches ultrabasiques de la côte Ouest de la Nouvelle-Calédonie: le Boulinda. Adansonia: 14(3) 311-336 pp. 
888 Kukier, U. and Chaney, R.L. (2001) Amelioration of nickel phytotoxicity in muck and mineral 889 soils. Journal Of Environmental Quality: 30(6), 1949-1960 pp.

891 L'Huillier, L., d'Auzac, J., Durand, M. and Michaud-Ferrière, N. (1996) Nickel effects on two 892 maize (Zea mays) cultivars: growth, structure, Ni concentration, and localization. Canadian journal 893 of botany: 74(10), 1547-1554 pp.

L'Huillier, L., and Edighoffer, S. (1996) Extractability of nickel and its concentration in cultivated 896 plants in Ni rich ultramafic soils of New Caledonia. Plant and Soil 186, 255-264.

Latham, M. (1975a). Les sols d'un massif de roches ultrabasiques de la Côte ouest de Nouvelle899 Caledonie: Le Boulinda. $1^{\text {ère }}$ partie. Généralités. Les sols à accumulation humifère. Cahiers 900 ORSTOM, Série Pedologie: 13, 27-40 pp.

902 Latham, M. (1975b) Les sols d'un massif de roches ultrabasiques de la Côte ouest de Nouvelle903 Caledonie: Le Boulinda. $2^{\text {ème }}$ partie. Les sols à accumulation ferrugineuse. Cahiers ORSTOM, Série 904 Pédologie: 13, 159-172 pp.

Lee, B.D., Sears, S.K., Graham, R.C., Amrhein, C., Vali, H. (2003) Secondary mineral genesis from chlorite and serpentine in an ultramafic soil toposequence. Soil Science Society of America Journal: 67, 1309-1317 pp.

910 Lewis, J.F., Draper, G., Espaillat, J., Proenza, J.A. and Jiménez, J. (2006) Ophiolite-related 911 ultramafic rocks (serpentinites) in the Caribbean region: A review of their occurrence, composition, 912 origin, emplacement and Ni-laterite soil formation. Geologica acta: an international earth science 913 journal: 4(1), 237-264 pp.

915 Leleyter, L. and Probst, J.L. (1999) A new sequential extraction procedure for the speciation of 916 particulate trace elements in river sediments. International Journal of Environmental Analytical Chemistry: 73, 109-128 pp.

Lindsay, W.L. and Norvell, W.A. (1978) Development of DTPA soil test for zinc, iron, manganese, and copper. Soil Science Society of America Journal: 42, 421-428 pp. 
922 Massoura, S.T., Echevarria, G., Becquer, T., Ghanbaja, J., Leclerc-Cessac, E., Morel, J.L. (2006)

923 Nickel bearing phases and availability in natural and anthropogenic soils. Geoderma: 136, 28-37 924 pp.

McManus, J. and Tate, R.B. (1986) Mud volcanoes and the origin of certain chaotic deposits in Sabah, East Malaysia. Bulletin of the Geological Society of Malaysia: 19, 193-205 pp.

Mehlich, A. (1984) Mehlich-3 soil test extractant: a modification of Mehlich-2 extractant. 930 Communications in Soil Science and Plant Analysis: 15(12): 1409-1416 pp.

Nagy, L., \& Proctor, J. (1997). Soil Mg and Ni as causal factors of plant occurrence and distribution at the Meikle Kilrannoch ultramafic site in Scotland. New Phytologist, 135(3), 561-566.

Oze, C., Fendorf, S., Bird, D.K. and Coleman, R.G. (2004) Chromium geochemistry in 936 serpentinized ultramafic rocks and serpentine soils from the Franciscan complex of California. 937 American Journal of Science: 304(1), 67-101 pp.

Proctor, J. (1970) Magnesium as a Toxic Element. Nature: 227(5), 742-743 pp.

Proctor, J. (2003) Vegetation and soil and plant chemistry on ultramafic rocks in the tropical Far East. Perspectives In Plant Ecology Evolution And Systematics: 6(1-2), 105-124 pp.

Proctor, J., Lee, Y.F., Langley, A.M., Munro, W. and Nelson, T. (1988) Ecological studies on Gunung Silam, a small ultrabasic mountain in Sabah, Malaysia. I. Environment, forest structure and

Proctor, J., Bruijnzeel, L.A., Baker, A.J.M. (1999) What causes the vegetation types on Mount Biogeography: 8, 347-354 pp.

952 Quantin, C., Becquer, T., Rouiller, J.H., Berthelin, J. (2002) Redistribution of metals in a New 953 Caledonia Ferralsol after microbial weathering. Soil Science Society of America Journal: 66(6), 954 1797-1804 pp. 
956

957

958

959

960

961

962

963

964

965

966

967

968

969

970

971

972

973

974

975

976

977

978

979

980

981

982

983

984

985

986

987

988

989

Raous, S., Echevarria, G., Sterckeman, T., Hanna, K., Thomas, F., Martins, E.S. \& Becquer, T. (2013) Potentially toxic metals in ultramafic mining materials: identification of the main bearing and reactive phases. Geoderma: 192, 111-119.

Rayment, G.E. and Higginson, F.R. (1992) Australian Laboratory Handbook of Soil and Water Chemical Methods. Inkata Press, Melbourne.

Repin, R. (1998) Serpentine ecology in Sabah, Malaysia. Sabah Parks Journal: 1, 19-28 pp.

Roqué-Rosell, J., Mosselmans, J.F.W., Proenza, J.A., Labrador, M., Galí, S., Atkinson, K.D. and Quinn, P.D. (2010) Sorption of Ni by "lithiophorite-asbolane" intermediates in Moa Bay lateritic deposits, eastern Cuba. Chemical Geology: 275, 9-18 pp.

Schwertmann, U. and Latham, M. (1986) Properties of iron oxides in some New Caledonian oxisols, Geoderma: 39, 105-123 pp.

Searle, M.P., Stevens, R.K. (1984) Obduction processes in ancient, modem and future ophiolites. In: Gass, I.G., Lippard, S.J., Shelton, A.W. (Eds.), Ophiolites and Oceanic Lithosphere. Blackwell, London, 303-319 pp.

Tashakor, M., Brearley, F. (2017) Geochemical assessment of metal transfer from rock and soil to water in serpentine areas of Sabah (Malaysia), Environmental and Earth Sciences: 76(7), 281, 13 pp.

Taylor, G.J., Stadt, K.J. and Dale, M.R.T. (1991) Modelling the phytotoxicity of aluminium, cadmium, copper, manganese, nickel and zinc using the Weibull frequency distribution. Canadian Journal of Botany: 69, 359-367 pp.

Trescases, J.J. (1975) L'évolution géochimique supergène des roches ultrabasiques en zone tropicale - Formation des gisements nickélifères de Nouvelle-Calédonie. Mémoire ORSTOM.

Vitousek, P.M., Sanford, R.L. (1986) Nutrient cycling in moist tropical forest. Annual Review of Ecology and Systematics: 17, 137-167 pp. 
990 Walker, R., Walker, H. and Ashworth, P. (1955) Calcium-magnesium nutrition with special 991 reference to serpentine soils. Plant Physiology: 30(3), 214-221 pp.

992

993 Whitmore, T.C., Peralta, R., Brown, K. (1985) Total species count in a Costa Rican tropical rain 994 forest. Journal of Tropical Ecology: 1(4), 375-378 pp.

995

996 Yongue-Fouateu, R., Ghogomu, R.T., Penaye, J., Ekodeck, G.E., Stendal, H., Colin, F. (2006)

997 Nickel and cobalt distribution in the laterites of the Lomié region, south-east Cameroon. Journal of 998 African Earth Sciences: 45, 33-47 pp.

999

1000 


\section{FIGURES}

Figure 1. Geological map of the study area with sampling sites marked (coloured circles)

Figure 2. Stacked XRD profiles for rock specimens, with diagnostic peaks and Miller indices provided for constituent minerals. ACT $=$ actinolite (here tremolite - an amphibole), ENST = enstatite (a pyroxene), DIOP = diopside (a pyroxene), FOR = forsterite $(\mathrm{Mg}$-rich olivine $), \mathrm{MAG}=$ magnetite, SERP = serpentine, SPIN = spinel, TALC as written.

Figure 3. Stacked XRD profiles for soil samples with diagnostic peaks and Miller indices provided

1011 for constituent minerals. ACT $=$ actinolite (here tremolite - an amphibole), ENST $=$ enstatite (a 1012 pyroxene), DIOP = diopside (a pyroxene), FOR = forsterite (Mg-rich olivine), MAG = magnetite, 1013 SERP $=$ serpentine, SPIN $=$ spinel, TALC, GOE $=$ goethite, $\mathrm{CHL}=$ chlorite, and $\mathrm{QTZ}=$ quartz as 1014 written.

1015

1016 Figure 4. Partitioning of Ni, Cr, Co over soil fractions (as percentage of total) of the four main soil 1017 types $(\mathrm{EX}=$ water soluble and exchangeable, $\mathrm{Mn}-\mathrm{OX}=$ bound to $\mathrm{Mn}$ oxides, $\mathrm{AM}-\mathrm{Fe}=$ bound to 1018 amorphous Fe oxides, CR-Fe, bound to crystalline Fe oxides, Res = residual. nominally outlined in the NMDS-plots (based on site typology). 
1026

1027

1028

1029

1030

1031

1032

1033

1034

1035

1036

1037

1038

1039

1040

1041

1042 1043

1044

1045

1046

1047

1048

1049

1050

1051

1052

1053

1054

1055

1056

1057

1058

1059

1060

\section{TABLES}

Table 1. Collection localities with environmental and pedological attributes (bedrock types, soil classes, soil depth).

Table 2. Bedrock chemistry (ranges and means) of ultramafic and non-ultramafic bedrock total values (pressurised $\mathrm{HF} / \mathrm{HCl} / \mathrm{HNO}_{3}$ microwave digest).

Table 3. Chemistry of ultramafic and non-ultramafic soils. Abbreviations: 'pseudo-total' microwave-assisted digestion with $\mathrm{HNO}_{3}$ and $\mathrm{HCl}$, 'DTPA' is DTPA-extractable metals, 'ML-3' is Mehlich-3 extractable $\mathrm{P}$, and 'exch.' is exchangeable with silver-thiourea.

Table 4. Soil pseudo-total elements of the main 'ultramafic edaphic islands' in $\mu \mathrm{g} \mathrm{g}^{-1} \mathrm{or} \mathrm{mg} \mathrm{g}^{-1}$ if marked with asterisk (as means from unpressurised $\mathrm{HNO}_{3} / \mathrm{HCl}$ microwave digests).

Table 5. Soil extractable (carboxylic acid) elements (Co, Fe, Mn, Ni) in $\mu \mathrm{g} \mathrm{g}^{-1}$, exchangeable elements ( $\mathrm{Al}, \mathrm{Ca}, \mathrm{K}, \mathrm{Mg}, \mathrm{Na})$ in $\mathrm{cmol}^{(+)} \mathrm{kg}^{-1}$ and Mehlich-3 extractable $\mathrm{P}\left(\mu \mathrm{g} \mathrm{g}{ }^{-1}\right)$, all as means.

Table 6. XRD modelled mineral relative abundances for selected rocks, assuming the sample is a mixture of crystalline diopside, tremolite (actinolite), antigorite, lizardite, spinel, talc, fosteritic olivine, and smectite group clay minerals. Total elemental concentrations in selected rock samples ( $\mu \mathrm{g} \mathrm{g}^{-1}$ or $\%$ if indicated).

Table 7. XRD modelled mineral relative abundances for selected soils, assuming the sample is a mixture of crystalline diopside, tremolite (actinolite), antigorite, lizardite, spinel, talc, fosteritic olivine, and smectite group clay minerals. Pseudo-total elemental concentrations in selected soil samples $\left(\mu \mathrm{g} \mathrm{g}^{-1}\right)$.

Table 8. Soil profiles: pseudo-total values for soil in $\mu \mathrm{g} \mathrm{g}^{-1}$ or $\mathrm{mg} \mathrm{g}^{-1}$ (elements marked with asterisk) total values for bedrock in $\%(\mathrm{Ca}, \mathrm{K}, \mathrm{Mg}, \mathrm{Al}, \mathrm{Fe}, \mathrm{Si})$ and $\mu \mathrm{g} \mathrm{g}{ }^{-1}(\mathrm{Co}, \mathrm{Cr}, \mathrm{Mn}, \mathrm{Ni}, \mathrm{P})$.

Table 9. Chemistry of tropical ultramafic soils from around the world. CEC and exchangeable cations with silver-thiorea, 2 CEC and exchangeable cations with ammonium acetate, 3 Olsen-P extract $\left(\mathrm{NaHCO}_{3}\right), 4$ Soil digestion with $\mathrm{HNO}_{3} / \mathrm{HCl}, 5$ Ammonium acetate extract, 6 Acetic acid extract/digestion, 7 Bray’s extract, 8 DTPA-extract, 9 Mehlich-3 extract. 
TABLE 1

\begin{tabular}{|c|c|c|c|c|c|c|c|c|}
\hline $\begin{array}{c}\text { Site } \\
\text { number }\end{array}$ & Locality & $\begin{array}{c}\mathbf{n} \\
\text { (soils) }\end{array}$ & $\begin{array}{l}\text { Altitude range } \\
\quad(\mathbf{m} \text { asl })\end{array}$ & $\begin{array}{l}\text { Slope } \\
(\%)\end{array}$ & Bedrock type & Soil class & $\begin{array}{c}\text { Soil } \\
\text { depth } \\
\text { (m) }\end{array}$ & O-A-horizon \\
\hline 1 & $\begin{array}{l}\text { Mt Tambuyukon } \\
\text { (summit) }\end{array}$ & 53 & $2318-2534$ & $20-50$ & Peridotite (Dunite) & $\begin{array}{l}\text { Eutric Leptic Cambisol } \\
\text { (hypermagnesic) }\end{array}$ & $<0.3$ & Absent \\
\hline 2 & $\begin{array}{l}\text { Mt Tambuyukon } \\
\text { (slopes) }\end{array}$ & 12 & 1466-1906 & $<20$ & Peridotite & $\begin{array}{l}\text { Dystric Folic Cambisol } \\
\text { (magnesic) }\end{array}$ & $<0.5$ & Mor accumulation \\
\hline 3 & Wuluh River & 35 & $750-820$ & $50-75$ & Serpentinite & $\begin{array}{c}\text { Mollic Leptosol (colluvic, } \\
\text { hypermagnesic) }\end{array}$ & $>1$ & Thin A-horizon \\
\hline 4 & Serinsim & 15 & $612-671$ & $<20$ & Peridotite & $\begin{array}{l}\text { Plinthic Geric Rhodic } \\
\text { Ferralsol }\end{array}$ & $>5$ & $\begin{array}{l}\text { Only leaf litter, iron } \\
\text { concretions }\end{array}$ \\
\hline 5 & Mt Nambuyukon & 9 & $1584-1590$ & $<20$ & Serpentinite & Dystric Ferralic Cambisol & $<1$ & Thin A - horizon \\
\hline 6 & Panataran Valley & 26 & $588-781$ & $20-50$ & Serpentinite & $\begin{array}{l}\text { Mollic Leptosol } \\
\text { (hypermagnesic) }\end{array}$ & $>1$ & Thin A - horizon \\
\hline 7 & Marai Parai & 34 & $2633-1753$ & $<20$ & Peridotite & Dystric Leptic Cambisol & $<0.3$ & Thin A - horizon \\
\hline 8 & Layang-Layang & 31 & $2305-2950$ & $20-50$ & $\begin{array}{l}\text { Non-serpentinised } \\
\text { Peridotite }\end{array}$ & $\begin{array}{c}\text { Eutric Leptic Cambisol } \\
\text { (hypermagnesic) }\end{array}$ & $<0.3$ & Absent \\
\hline 9 & Mesilau & 25 & 1909-2067 & $<20$ & $\begin{array}{l}\text { Partially serpentinised } \\
\text { Peridotite with Tremolite }\end{array}$ & $\begin{array}{c}\text { Folic Hypereutric Cambisol } \\
\text { (hypermagnesic) }\end{array}$ & $<1$ & Mor accumulation \\
\hline 10 & Bukit Babi & 18 & $1877-2286$ & $20-50$ & Peridotite & $\begin{array}{c}\text { Dystric Folic Cambisol } \\
\text { (hypermagnesic) }\end{array}$ & $<1$ & Mor accumulation \\
\hline 11 & Bambangan & 27 & $1683-2077$ & $50-75$ & Serpentinite & $\begin{array}{l}\text { Mollic Leptosol } \\
\text { (hypermagnesic) }\end{array}$ & $<1$ & Thin A-horizon \\
\hline 12 & Bukit Hampuan & 28 & 963-1336 & $50-75$ & Mixed & $\begin{array}{l}\text { Mollic Leptosol } \\
\text { (hypermagnesic) }\end{array}$ & $0.5-1$ & Thin A-horizon \\
\hline 13 & Nalumad & 12 & $754-836$ & $<20$ & Peridotite & $\begin{array}{l}\text { Plinthic Rhodic Ferralsol } \\
\text { (magnesic) }\end{array}$ & $>5$ & $\begin{array}{l}\text { Only leaf litter, iron } \\
\text { concretions }\end{array}$ \\
\hline
\end{tabular}


TABLE 2

\begin{tabular}{|c|c|c|c|c|c|}
\hline \multirow{2}{*}{$\begin{array}{c}\text { Ultramafic } \\
\text { Al }\end{array}$} & \multirow{2}{*}{$\frac{\text { Unit }}{\%}$} & \multicolumn{2}{|c|}{ Ultramafic bedrock $(n=76)$} & \multicolumn{2}{|c|}{ Non-ultramafic bedrock $(n=13)$} \\
\hline & & $0.02-19$ & 3 & $0.1-10$ & 5 \\
\hline $\mathbf{C a}$ & $\%$ & $0.01-12$ & 2 & $0.002-10$ & 1 \\
\hline Co & $\mu \mathrm{g} \mathrm{g}^{-1}$ & $3-27$ & 8 & $3-11$ & 5 \\
\hline $\mathrm{Cr}$ & $\mu \mathrm{g} \mathrm{g}^{-1}$ & $8-8604$ & 1441 & $11-906$ & 188 \\
\hline $\mathbf{C u}$ & $\mu \mathrm{g} \mathrm{g}^{-1}$ & $0.1-620$ & 46 & $0.1-170$ & 25 \\
\hline $\mathbf{F e}$ & $\%$ & $0.06-43$ & 5 & $0.1-5$ & 2 \\
\hline $\mathbf{K}$ & $\%$ & $0.01-3$ & 0.3 & $0.01-2$ & 1 \\
\hline Mg & $\%$ & $0.05-53$ & 19 & $0.1-28$ & 5 \\
\hline Mn & $\mu \mathrm{g} \mathrm{g}^{-1}$ & $31-3264$ & 1237 & $31-2869$ & 560 \\
\hline $\mathbf{N a}$ & $\%$ & $0.01-3$ & $\mathbf{0}$ & $0.02-2$ & 1 \\
\hline $\mathbf{N i}$ & $\mu \mathrm{g} \mathrm{g}^{-1}$ & $16-4775$ & 939 & $15-1315$ & 225 \\
\hline $\mathbf{P}$ & $\mu \mathrm{g} \mathrm{g}^{-1}$ & $2.3-804$ & 72 & $40-571$ & 142 \\
\hline $\mathbf{S}$ & $\%$ & $0.01-0.11$ & 0.05 & $0.01-0.1$ & 0.1 \\
\hline $\mathbf{S i}$ & $\%$ & $0.4-36$ & 15 & $2-36$ & 21 \\
\hline $\mathbf{Z n}$ & $\mu \mathrm{g} \mathrm{g}^{-1}$ & $3.5-208$ & 59 & $4-148$ & 43 \\
\hline
\end{tabular}




\section{TABLE 3}

\begin{tabular}{|c|c|c|c|c|c|c|}
\hline \multirow{2}{*}{$\begin{array}{c}\text { Ultramafic } \\
\text { Al }\end{array}$} & \multirow{2}{*}{$\begin{array}{c}\text { Extract } \\
\text { Total }\end{array}$} & \multirow{2}{*}{$\begin{array}{c}\text { Unit } \\
\mathrm{mg} \mathrm{g}^{-1}\end{array}$} & \multicolumn{2}{|c|}{ Ultramafic soils $(n=423)$} & \multicolumn{2}{|c|}{ Non-ultramafic soils $(n=67)$} \\
\hline & & & $1.2-118$ & 19 & $0.3-92$ & 19 \\
\hline $\mathbf{C a}$ & Total & $\mu \mathrm{g} \mathrm{g}^{-1}$ & $7.7-39300$ & 2433 & $2.2-12380$ & 541 \\
\hline Co & Total & $\mu \mathrm{g} \mathrm{g}^{-1}$ & $0.5-1524$ & 253 & $0.5-26$ & 7.7 \\
\hline $\mathrm{Cr}$ & Total & $\mu g \mathrm{~g}^{-1}$ & $121-21710$ & 3873 & $2.4-170$ & 36 \\
\hline $\mathbf{C u}$ & Total & $\mu g \mathrm{~g}^{-1}$ & $2.4-453$ & 47 & $0.04-83$ & 16 \\
\hline $\mathbf{F e}$ & Total & $\mathrm{mg} \mathrm{g}^{-1}$ & $21-535$ & 144 & $0.1-121$ & 16 \\
\hline $\mathbf{K}$ & Total & $\mu \mathrm{g} \mathrm{g^{-1 }}$ & $<0.1-1056$ & 93 & $38-7297$ & 1065 \\
\hline Mg & Total & $\mathrm{mg} \mathrm{g}^{-1}$ & $0.3-235$ & 32 & $0.03-18$ & 1.9 \\
\hline Mn & Total & $\mathrm{mg} \mathrm{g}^{-1}$ & $0.04-34$ & 3 & $<0.01-1.5$ & 0.1 \\
\hline $\mathbf{N a}$ & Total & $\mu \mathrm{g} \mathrm{g}^{-1}$ & $<0.1-361$ & 146 & $2.4-132$ & 55 \\
\hline $\mathrm{Ni}$ & Total & $\mu \mathrm{g} \mathrm{g}^{-1}$ & $17-9308$ & 1623 & $0.5-338$ & 28 \\
\hline $\mathbf{P}$ & Total & $\mu \mathrm{g} \mathrm{g}^{-1}$ & $4.4-585$ & 127 & $20-532$ & 121 \\
\hline $\mathbf{S}$ & Total & $\mu \mathrm{g} \mathrm{g}^{-1}$ & $33-6172$ & 371 & $64-641$ & 212 \\
\hline $\mathbf{Z n}$ & Total & $\mu \mathrm{g} \mathrm{g}^{-1}$ & $13-373$ & 107 & $1.2-111$ & 19 \\
\hline pH & $1: 2.5 \mathrm{H}_{2} \mathrm{O}$ & - & $3.8-9.7$ & 6.0 & $3.5-7.2$ & 4.6 \\
\hline EC & $1: 2.5 \mathrm{H}_{2} \mathrm{O}$ & $\mu \mathrm{S}$ & $9.0-939$ & 165 & $18-291$ & 74 \\
\hline Al & DTPA & $\mu \mathrm{g} \mathrm{g}^{-1}$ & $0.03-522$ & 14 & $2.5-850$ & 337 \\
\hline $\mathbf{C a}$ & Exch. & $\mu \mathrm{g} \mathrm{g}^{-1}$ & $0.6-6946$ & 402 & $17-3394$ & 125 \\
\hline Co & DTPA & $\mu \mathrm{g} \mathrm{g}^{-1}$ & $0.04-96$ & 17 & $<0.1-0.9$ & 0.2 \\
\hline $\mathrm{Cr}$ & DTPA & $\mu \mathrm{g} \mathrm{g}^{-1}$ & $<0.1-13$ & 0.4 & $<0.1-0.7$ & 0.1 \\
\hline $\mathrm{Cu}$ & DTPA & $\mu \mathrm{g} \mathrm{g}^{-1}$ & $<0.1-26$ & 1.7 & $<0.1-7.4$ & 0.7 \\
\hline $\mathrm{Fe}$ & DTPA & $\mu \mathrm{g} \mathrm{g}^{-1}$ & $0.5-873$ & 96 & $2.9-737$ & 159 \\
\hline $\mathbf{K}$ & Exch. & $\mu \mathrm{g} \mathrm{g}^{-1}$ & $0.7-307$ & 36 & $2.5-191$ & 38 \\
\hline Mg & Exch. & $\mu \mathrm{g} \mathrm{g}^{-1}$ & $1.8-9155$ & 942 & $0.2-57$ & 12 \\
\hline Mn & DTPA & $\mu \mathrm{g} \mathrm{g}^{-1}$ & $0.4-822$ & 215 & $0.1-40$ & 3.6 \\
\hline $\mathrm{Na}$ & Exch. & $\mu \mathrm{g} \mathrm{g}^{-1}$ & $1.5-1652$ & 103 & $0.2-89$ & 11 \\
\hline $\mathbf{N i}$ & DTPA & $\mu \mathrm{g} \mathrm{g}^{-1}$ & $0.2-442$ & 62 & $0.03-3.3$ & 0.3 \\
\hline $\mathbf{P}$ & ML-3 & $\mu \mathrm{g} \mathrm{g}^{-1}$ & $<0.1-32$ & 2.7 & $1.7-80$ & 12 \\
\hline $\mathbf{S}$ & DTPA & $\mu g \mathrm{~g}^{-1}$ & $0.9-683$ & 24 & $1.0-33$ & 6.5 \\
\hline Zn & DTPA & $\mu g \mathrm{~g}^{-1}$ & $0.02-161$ & 1.2 & $0.05-16$ & 0.9 \\
\hline Mg:Ca & Exch. & - & $<0.1-82$ & 5.3 & $<0.1-1.0$ & 0.2 \\
\hline
\end{tabular}


TABLE 4

\begin{tabular}{|c|c|c|c|c|c|c|c|c|c|c|c|}
\hline Site & $\mathbf{n}$ & $\mathbf{p H}$ & $\mathbf{A l} \mathbf{I}^{*}$ & $\mathbf{C a}$ & $\mathbf{C o}$ & $\mathbf{C r}$ & $\mathbf{F e}$ & $\mathbf{K}$ & $\mathbf{M g}$ & $\mathbf{M n}$ & $\mathbf{N i}$ \\
\hline Bambangan & 27 & 6.2 & 22.5 & 5990 & 214 & 3.7 & 95.8 & 75 & 40 & 2.8 & 1090 \\
\hline Bukit Babi & 18 & 5.5 & 11.8 & 654 & 162 & 3.1 & 70.9 & 29 & 13 & 2.2 & 346 \\
\hline Bukit Hampuan & 28 & 6.2 & 26.6 & 4028 & 318 & 4.7 & 137.8 & 90 & 28 & 3.9 & 1798 \\
\hline Layang-Layang & 31 & 5.1 & 11.6 & 867 & 120 & 0.6 & 86.9 & 148 & 12 & 1.5 & 956 \\
\hline Marai Parai & 34 & 5.3 & 21.3 & 698 & 69 & 3.4 & 75.8 & 44 & 24 & 0.7 & 442 \\
\hline Mesilau & 25 & 6.2 & 12.4 & 909 & 156 & 0.7 & 78.6 & 136 & 57 & 2.0 & 1409 \\
\hline Serinsim & 15 & 4.7 & 30.8 & 561 & 50 & 16.3 & 385.7 & 83 & 0.5 & 2.3 & 2452 \\
\hline Mt Tambuyukon summit & 53 & 6.0 & 6.3 & 882 & 464 & 3.2 & 216.8 & 96 & 12.0 & 6.4 & 2137 \\
\hline Mt Tambuyukon slopes & 12 & 5.5 & 17.9 & 651 & 737 & 8.8 & 312.0 & 83 & 4.9 & 7.7 & 2476 \\
\hline Wuluh River & 35 & 7.3 & 5.5 & 1761 & 177 & 2.5 & 72.7 & 65 & 120 & 2.3 & 2268 \\
\hline Mt Nambuyukon & 9 & 5.2 & 60.7 & 1186 & 165 & 3.8 & 188.2 & 87 & 6.2 & 2.1 & 779 \\
\hline Nalumad & 12 & 4.6 & 31.4 & 578 & 124 & 6.1 & 233.2 & 160 & 0.6 & 3.1 & 902 \\
\hline Panataran Valley & 26 & 6.5 & 26.5 & 9324 & 242 & 2.5 & 122.3 & 102 & 56 & 3.3 & 1496 \\
\hline
\end{tabular}


TABLE 5

\begin{tabular}{|c|c|c|c|c|c|c|c|c|c|c|c|c|c|}
\hline Site & $\mathbf{n}$ & Co & $\mathbf{F e}$ & Mn & $\mathbf{N i}$ & Al & $\mathbf{C a}$ & $\mathbf{K}$ & Mg & $\mathbf{N a}$ & Mg:Ca & CEC & $\mathbf{P}$ \\
\hline Bambangan & 27 & 15 & 443 & 236 & 34 & 0.02 & 1.7 & 0.09 & 9.9 & 0.3 & 8.1 & 12.0 & 2.7 \\
\hline Bukit Babi & 18 & 32 & 388 & 583 & 20 & 0.02 & 0.7 & 0.10 & 1.3 & 1.0 & 2.4 & 3.2 & 2.0 \\
\hline Bukit Hampuan & 28 & 36 & 633 & 435 & 68 & 0.03 & 5.1 & 0.13 & 13.8 & 0.7 & 11.7 & 19.8 & 4.0 \\
\hline Layang-Layang & 31 & 11 & 388 & 226 & 21 & 0.20 & 0.8 & 0.10 & 1.7 & 0.5 & 6.0 & 3.4 & 4.0 \\
\hline Marai Parai & 34 & 4 & 98 & 73 & 13 & 0.12 & 0.3 & 0.05 & 1.0 & 0.1 & 3.8 & 1.6 & 1.8 \\
\hline Mesilau & 25 & 9 & 616 & 157 & 31 & 0.02 & 1.3 & 0.08 & 10.1 & 0.2 & 12.8 & 11.8 & 3.5 \\
\hline Serinsim & 15 & 2 & 73 & 30 & 3 & 0.04 & 0.3 & 0.08 & 0.2 & 0.1 & 0.8 & 0.6 & 1.3 \\
\hline Mt Tambuyukon summit & 53 & 106 & 560 & 1512 & 139 & 0.01 & 1.1 & 0.09 & 3.5 & 1.1 & 5.7 & 5.8 & 1.1 \\
\hline Mt Tambuyukon slopes & 12 & 156 & 528 & 1542 & 38 & 0.01 & 0.4 & 0.07 & 1.1 & 1.3 & 10.4 & 2.8 & 1.4 \\
\hline Wuluh River & 35 & 20 & 553 & 259 & 152 & 0.09 & 1.2 & 0.06 & 14.6 & 0.1 & 21.4 & 16.0 & 2.3 \\
\hline Mt Nambuyukon & 9 & 15 & 104 & 166 & 3 & 1.17 & 0.7 & 0.05 & 0.4 & 0.3 & 0.8 & 2.6 & 1.7 \\
\hline Nalumad & 12 & 29 & 121 & 311 & 7 & 1.32 & 0.3 & 0.11 & 0.2 & 0.4 & 1.2 & 2.3 & 2.5 \\
\hline Panataran Valley & 26 & 25 & 671 & 370 & 66 & 0.01 & 4.8 & 0.11 & 16.3 & 0.6 & 5.3 & 21.9 & 2.9 \\
\hline
\end{tabular}


TABLE 6

\begin{tabular}{|c|c|c|c|c|c|}
\hline Locality & $\begin{array}{l}\text { Layang- } \\
\text { Layang }\end{array}$ & Bambangan & $\begin{array}{c}\text { Mt. } \\
\text { Tambuyukon } \\
\text { (summit) }\end{array}$ & $\begin{array}{c}\text { Mt. } \\
\text { Tambuyukon } \\
\text { (summit) }\end{array}$ & Mesilau \\
\hline Site number & 8 & 11 & 1 & 1 & 9 \\
\hline diopside & 21.8 & 4.5 & 0.4 & 3.1 & 4.9 \\
\hline tremolite & 5 & 2.6 & 0.3 & 2.4 & 10.7 \\
\hline antigorite & 28.6 & 29.1 & 32.1 & 24.3 & 23.8 \\
\hline lizardite & 7.5 & 17.8 & 26.8 & 27.2 & 12.9 \\
\hline spinel & 2.9 & 8.1 & 5.7 & 7.3 & 9.2 \\
\hline talc & 4.2 & 4.9 & 1.5 & 2.7 & 5.5 \\
\hline forsterite & 29.7 & 32.6 & 33 & 32.6 & 32.6 \\
\hline $\begin{array}{c}\text { smectite group } \\
\text { clays }\end{array}$ & 0.3 & 0.4 & 0.3 & 0.3 & 0.4 \\
\hline Al \% & 1.7 & 1.1 & 0.03 & 0.02 & 0.4 \\
\hline $\mathrm{Ca} \%$ & 4.4 & 0.2 & 0.02 & 0.2 & 0.7 \\
\hline Co & 6 & 8 & 9 & 8 & 10 \\
\hline $\mathrm{Cr}$ & 1287 & 2735 & 239 & 212 & 1571 \\
\hline $\mathrm{Cu}$ & 19 & 36 & 13 & 33 & 5 \\
\hline Fe $\%$ & 6.1 & 5.6 & 2.5 & 4.5 & 5 \\
\hline K \% & 0.02 & 0.007 & 0.009 & 0.003 & 0.005 \\
\hline Mg \% & 20.4 & 29.4 & 16.5 & 24.7 & 22.2 \\
\hline Mn & 1394 & 1287 & 867 & 1089 & 1486 \\
\hline $\mathrm{Na} \%$ & 0.08 & 0.01 & 0.03 & 0.01 & 0.01 \\
\hline $\mathbf{N i}$ & 775 & 1205 & 1265 & 1266 & 1078 \\
\hline $\mathbf{P}$ & 52 & 25 & 13 & 23 & 27 \\
\hline S \% & 0.04 & 0.09 & 0.06 & 0.02 & 0.04 \\
\hline Si \% & 14.5 & 16.1 & 13.4 & 12.5 & 9.3 \\
\hline $\mathbf{T i}$ & 963 & 124 & 31 & 22 & 85 \\
\hline $\mathbf{Z n}$ & 45 & 75 & 44 & 59 & 69 \\
\hline
\end{tabular}


TABLE 7

\begin{tabular}{|c|c|c|c|c|c|c|c|c|c|}
\hline Locality & Bambangan & Bukit Babi & $\begin{array}{l}\text { Layang- } \\
\text { Layang }\end{array}$ & $\begin{array}{c}\text { Marai } \\
\text { Parai }\end{array}$ & Mesilau & $\begin{array}{c}\text { Mt } \\
\text { Tambuyukon }\end{array}$ & $\begin{array}{c}\text { Mt } \\
\text { Tambuyukon }\end{array}$ & $\begin{array}{l}\text { Wuluh } \\
\text { River }\end{array}$ & Serinsim \\
\hline Site number & 11 & 10 & 8 & 7 & 9 & 1 & 1 & 3 & 4 \\
\hline diopside & 0.5 & 1.4 & 3.5 & 1.1 & 2.8 & 1.3 & 2.4 & 0 & 1.5 \\
\hline tremolite & 12.7 & 22.4 & 22.8 & 17.2 & 25.9 & 13.7 & 16.5 & 0 & 17.3 \\
\hline antigorite & 21 & 28.1 & 24.5 & 25.9 & 23.1 & 22.4 & 19.2 & 23.1 & 18 \\
\hline lizardite & 9 & 9.7 & 8.7 & 8.4 & 7.5 & 11 & 7.6 & 35.1 & 6.7 \\
\hline spinel & 8 & 5.8 & 10.4 & 6 & 7.4 & 14.1 & 13.6 & 10.9 & 28.9 \\
\hline talc & 27.2 & 11.5 & 1.9 & 15.3 & 11.1 & 7.5 & 17.1 & 1.8 & 5 \\
\hline forsterite & 20.6 & 19.7 & 17.8 & 24.9 & 20 & 28.6 & 22.5 & 28.7 & 21.4 \\
\hline smectite group clays & 1 & 1.5 & 1.4 & 1.2 & 2.2 & 1.3 & 1.1 & 0.4 & 1.1 \\
\hline $\mathbf{A l} *$ & 28.7 & 26.8 & 39.7 & 18.9 & 29.5 & 5.4 & 6.5 & 2.1 & 33.5 \\
\hline $\mathbf{C a}$ & 3990 & 670 & 2524 & 446 & 2788 & 510 & 325 & 75 & 28 \\
\hline Co & 236 & 102 & 63 & 72 & 176 & 417 & 185 & 103 & 4 \\
\hline $\mathrm{Cr}$ & 4071 & 2800 & 474 & 4934 & 1176 & 1742 & 1494 & 899 & 10530 \\
\hline $\mathbf{C u}$ & 21 & 13 & 56 & 21 & 28 & 15 & 7 & 3 & 50 \\
\hline $\mathbf{F e}^{*}$ & 101.6 & 88.4 & 73 & 216.1 & 155.4 & 238.2 & 164.5 & 43 & 349 \\
\hline $\mathbf{K}$ & 19 & 56 & 1904 & 23 & 68 & 32 & 39 & $<0.01$ & $<0.01$ \\
\hline Mg* & 30.2 & 42.1 & 11.8 & 15 & 35.3 & 13.4 & 6.4 & 198.7 & 1.5 \\
\hline Mn & 4115 & 1441 & 748 & 1193 & 2534 & 7582 & 3120 & 922 & 2508 \\
\hline $\mathbf{N a}$ & 61 & 16 & 113 & $<0.01$ & 115 & 53 & 37 & $<0.01$ & $<0.01$ \\
\hline $\mathbf{N i}$ & 641 & 487 & 236 & 773 & 1368 & 2031 & 1109 & 1131 & 2609 \\
\hline $\mathbf{P}$ & 77 & 62 & 167 & 81 & 130 & 116 & 42 & 11 & 205 \\
\hline $\mathbf{S}$ & 318 & 343 & 531 & 395 & 296 & 415 & 367 & 89 & 1881 \\
\hline
\end{tabular}


TABLE 8

\begin{tabular}{|c|c|c|c|c|c|c|c|c|c|c|c|c|c|c|c|}
\hline Depth (m) & pH & EC & $\mathbf{C a}$ & $\mathbf{K}$ & Mg & Mg:Ca & $\mathbf{A l} *$ & Co & Cr* & $\mathbf{F e}^{*}$ & Mn & $\mathbf{N i}$ & Ni ML-3 & $\mathbf{P}$ & Si \\
\hline \multicolumn{16}{|c|}{ Sunsui } \\
\hline $0-5$ & 4.4 & 55 & 224 & 13 & 17 & 0.1 & 16 & 5 & 0.9 & 76 & 96 & 55 & 1.1 & 43 & - \\
\hline $5-9$ & 5.7 & 12 & 226 & 13 & 237 & 1.1 & 19 & 18 & 1.0 & 98 & 408 & 144 & 3.5 & 35 & - \\
\hline $5-9$ & 5.8 & 169 & 611 & 51 & 2142 & 3.5 & 27 & 150 & 1.1 & 109 & 3157 & 1478 & 92 & 142 & - \\
\hline $9-10$ & 6.1 & 891 & 667 & 34 & 3996 & 6.0 & 17 & 66 & 0.8 & 51 & 467 & 1960 & 318 & 51 & - \\
\hline $10-14$ & 6.3 & 196 & 744 & 129 & 4852 & 6.5 & 17 & 114 & 0.9 & 102 & 2014 & 1810 & 52 & 100 & - \\
\hline $14-18$ & 6.7 & 100 & 905 & 57 & 6179 & 6.8 & 18 & 180 & 0.8 & 91 & 2043 & 2083 & 43 & 104 & - \\
\hline $18-22$ & 6.9 & 195 & 1043 & 90 & 3423 & 3.3 & 6 & 157 & 0.8 & 86 & 1648 & 3072 & 111 & 32 & - \\
\hline Bedrock & - & - & 6 & 1 & 420 & - & 9 & 70 & 694 & 68 & 1210 & 953 & - & 49 & 226 \\
\hline \multicolumn{16}{|c|}{ Hampuan } \\
\hline $0-4$ & 6.0 & 18 & 231 & 13 & 18 & 0.1 & 100 & 878 & 14.6 & 395 & 6931 & 2509 & 0.4 & 106 & - \\
\hline $4-7$ & 6.2 & 10 & 230 & 13 & 137 & 0.6 & 92 & 671 & 15.8 & 383 & 7033 & 3583 & 2.1 & 92 & - \\
\hline $7-16$ & 5.6 & 13 & 220 & 16 & 31 & 0.1 & 89 & 1055 & 15.8 & 372 & 8106 & 3101 & 0.7 & 74 & - \\
\hline $16-26$ & 6.5 & 55 & 465 & 9.2 & 3389 & 7.3 & 37 & 1040 & 14.0 & 352 & 8728 & 6985 & 44 & 47 & - \\
\hline $26-30$ & 7.6 & 85 & 686 & 11 & 6312 & 9.2 & 13 & 694 & 5.1 & 254 & 7540 & 9308 & 102 & 41 & - \\
\hline $30-36$ & 7.2 & 132 & 950 & 5.2 & 9155 & 9.6 & 34 & 597 & 9.0 & 176 & 7512 & 7164 & 129 & 20 & - \\
\hline Bedrock & - & - & 12 & 0.2 & 126 & - & 7 & 8 & 1244 & 23 & 1032 & 963 & - & 67 & 3.9 \\
\hline \multicolumn{16}{|c|}{ Serinsim } \\
\hline $0-0.1$ & 5.1 & 74 & 207 & 29 & 28 & 0.1 & 33 & 151 & 17.6 & 426 & 4754 & 2532 & 19 & 443 & - \\
\hline $0.3-0.4$ & 5.3 & 55 & 208 & 14 & 12 & 0.1 & 31 & 19 & 16.9 & 407 & 3243 & 2622 & 1.9 & 149 & - \\
\hline $0.8-0.9$ & 5.3 & 29 & 212 & 6.6 & 10 & 0.0 & 36 & 181 & 19.9 & 453 & 3493 & 3205 & 0.7 & 186 & - \\
\hline Bedrock & - & - & 0.4 & 0.4 & 256 & - & 6 & 13 & 1909 & 57 & 3124 & 2460 & - & 53 & 11 \\
\hline \multicolumn{16}{|c|}{ Wuluh River 1} \\
\hline $0-0.05$ & 6.4 & 180 & 236 & 36 & 1733 & 7.3 & 2.5 & 93 & 2.2 & 41 & 1358 & 1835 & 68 & 80 & - \\
\hline $0.5-0.1$ & 7.1 & 116 & 220 & 23 & 1115 & 5.1 & 2.6 & 96 & 2.4 & 40 & 1292 & 1669 & 52 & 59 & - \\
\hline $0.1-0.3$ & 7.4 & 112 & 197 & 4.5 & 331 & 1.7 & 2.3 & 107 & 2.4 & 45 & 1517 & 2181 & 18 & 12 & - \\
\hline $0.3-0.5$ & 8.5 & 142 & 180 & 1.8 & 173 & 1.0 & 2.3 & 86 & 2.7 & 40 & 1310 & 1723 & 2.1 & 20 & - \\
\hline $0.5-0.75$ & 9.2 & 726 & 204 & 5.1 & 6218 & 30.4 & 2.1 & 82 & 2.1 & 39 & 1233 & 1829 & 6.6 & 13 & - \\
\hline Bedrock & - & - & 1.8 & 0.05 & 326 & - & 4.7 & 8 & 2455 & 42.5 & 860 & 1111 & - & 24 & 13 \\
\hline
\end{tabular}


TABLE 9

\begin{tabular}{|c|c|c|c|c|c|c|c|c|c|}
\hline \multirow[b]{2}{*}{ Soil parameter } & \multirow[b]{2}{*}{ Unit } & \multirow[b]{2}{*}{ Cuba } & \multirow[b]{2}{*}{ Brazil* } & \multirow{2}{*}{$\begin{array}{c}\text { New } \\
\text { Caledonia }\end{array}$} & \multirow{2}{*}{$\begin{array}{l}\text { Indonesia } \\
\text { (Sulawesi) }\end{array}$} & \multirow{2}{*}{$\begin{array}{l}\text { Indonesia } \\
\text { (Sulawesi) }\end{array}$} & \multirow{2}{*}{$\begin{array}{l}\text { Indonesia } \\
\text { (Mt Piapi) }\end{array}$} & \multirow{2}{*}{$\begin{array}{c}\text { Philippines } \\
\text { Mt Giting-- } \\
\text { Giting }\end{array}$} & \multirow{2}{*}{$\begin{array}{c}\text { Malaysia } \\
(\text { Mt Kinabalu })\end{array}$} \\
\hline & & & & & & & & & \\
\hline Altitude & $\mathrm{m}$ asl & - & $750-1100$ & - & - & $200-300$ & $60-500$ & $325-1540$ & $400-2900$ \\
\hline pH & - & - & & $4.4-6.9$ & $5.3-6.3$ & $5.8-6.1$ & $6.1-6.4$ & $4.3-5.5$ & $3.8-9.7$ \\
\hline CEC & $\mathrm{cmol}^{(+)} \mathrm{kg}^{-1}$ & - & $0.3-82.9$ & $1.2-34$ & & $43-67^{6}$ & $15-44$ & - & $0.03-128^{1}$ \\
\hline Mg:Ca & - & - & $8.3-24$ & $0.8-23$ & $0.9-5.7$ & $0.6-2.1^{6}$ & $1.6-32$ & $0.3-2.9^{2}$ & $0.1-136^{1}$ \\
\hline Ca (exch.) & $\mathrm{cmol}^{(+)} \mathrm{kg}^{-1}$ & - & $0.015-1.9$ & $0.01-1.8$ & $4.6-13.3$ & $0.6-0.1^{6}$ & $0.9-16$ & $0.5-3.4^{2}$ & $0.003-35^{1}$ \\
\hline Ca (pseudo-total) & $\mu \mathrm{g} \mathrm{g}^{-1}$ & 4800 & $0-13500$ & - & - & - & - & - & $7.7-39300$ \\
\hline Mg (exch.) & $\mathrm{cmol}^{(+)} \mathrm{kg}^{-1}$ & - & $0.004-1.9$ & $0.2-38.5$ & $11.1-26.2$ & $0.52-1.18^{6}$ & $13.9-27.3$ & $0.75-3.64^{2}$ & $0.02-76^{1}$ \\
\hline Mg (pseudo-total) & $\mathrm{mg} / \mathrm{g}$ & - & $12-154$ & - & - & - & & - & $0.27-235$ \\
\hline K (exch.) & $\mathrm{cmol}^{(+)} \mathrm{kg}^{-1}$ & - & - & $0.02-0.2$ & $0.05-0.5$ & $0.03-0.10^{6}$ & $0.19-0.38$ & $0.04-0.41^{2}$ & $0.002-0.79^{1}$ \\
\hline K (pseudo-total) & $\mu \mathrm{g} \mathrm{g}^{-1}$ & 740 & - & - & - & $5164-6260^{4}$ & - & - & $0.1-1056$ \\
\hline P (pseudo-total) & $\mu \mathrm{g} \mathrm{g}^{-1}$ & 1724 & $<100$ & $393-509$ & - & $95-237^{4}$ & - & - & $4.4-585$ \\
\hline $\mathbf{P}$ (extract.) & $\mu \mathrm{g} \mathrm{g}^{-1}$ & & - & $140-310$ & - & $1.7-3.8^{7}$ & $0.94-6.8^{3}$ & $0.41-2.07^{3}$ & $0.1-32^{9}$ \\
\hline Fe (pseudo-total) & $\mathrm{mg} \mathrm{g}^{-1}$ & 196 & $154-466$ & - & - & $132-293$ & - & - & $21-535$ \\
\hline Ni (pseudo-total) & $\mu \mathrm{g} \mathrm{g}^{-1}$ & 4674 & $7744-18520$ & $1300-10400$ & $825-4050$ & $3730-7051^{4}$ & - & - & $17-9308$ \\
\hline $\mathbf{N i}$ (extract.) & $\mu \mathrm{g} \mathrm{g}^{-1}$ & & $0-1232$ & $0.2-66$ & & $6.0-7.5^{6}$ & $8.5-37^{5}$ & $1-24^{5}$ & $0.17-442^{8}$ \\
\hline Cr (pseudo-total) & $\mathrm{mg} \mathrm{g}^{-1}$ & 3.8 & $11200-46800$ & $6.3-56$ & $1.0-9.9$ & $9.5-17^{4}$ & - & - & $121-21710$ \\
\hline $\mathbf{C r}($ extract.) & $\mu \mathrm{g} \mathrm{g}^{-1}$ & - & 80-980 & $0.6-8.1$ & 1 & - & - & - & $<0.1-13^{8}$ \\
\hline Co (pseudo-total) & $\mu \mathrm{g} \mathrm{g}^{-1}$ & 381 & $413-799$ & $230-1300$ & - & $57-337^{4}$ & - & - & $0.5-1524$ \\
\hline Co (extract.) & $\mu \mathrm{g} \mathrm{g}^{-1}$ & - & - & $76-116^{8}$ & - & & - & - & $0.04-96^{8}$ \\
\hline References & & $\begin{array}{c}\text { Reeves et } \\
\text { al., } 1999\end{array}$ & $\begin{array}{l}\text { Raous et al. } \\
2013\end{array}$ & Jaffré, 1980 & Parry, 1985 & Tjoa, 2011 & $\begin{array}{c}\text { Proctor et al., } \\
1994 \\
\end{array}$ & $\begin{array}{c}\text { Proctor et al., } \\
1998\end{array}$ & This research \\
\hline
\end{tabular}

NOTES: ${ }^{1}$ CEC and exchangeable cations with silver-thiourea, ${ }^{2} \mathrm{CEC}$ and exchangeable cations with ammonium acetate, ${ }^{3} \mathrm{Olsen}_{\mathrm{P}} \mathrm{P}$ extract $(\mathrm{NaHCO}),{ }^{4} \mathrm{Soil}$ digestion with $\mathrm{HNO}_{3} / \mathrm{HCl},{ }^{5}$ Ammonium acetate extract, ${ }^{6}$ Acetic acid extract/digestion, ${ }^{7}$ Bray's extract, ${ }^{8}$ DTPA-extract, ${ }^{9}$ Mehlich-3 extract. ${ }^{*}$ Total concentrations instead of pseudo-total. 